Portland State University

PDXScholar

Dissertations and Theses

Dissertations and Theses

Spring 5-28-2015

\title{
Discursive Security: F.B.I. Stings and the Nature of Peace
}

\author{
Adam Testerman \\ Portland State University
}

Follow this and additional works at: https://pdxscholar.library.pdx.edu/open_access_etds

Part of the National Security Law Commons, and the Other Communication Commons Let us know how access to this document benefits you.

\section{Recommended Citation}

Testerman, Adam, "Discursive Security: F.B.I. Stings and the Nature of Peace" (2015). Dissertations and Theses. Paper 2351.

https://doi.org/10.15760/etd.2348

This Thesis is brought to you for free and open access. It has been accepted for inclusion in Dissertations and Theses by an authorized administrator of PDXScholar. For more information, please contact pdxscholar@pdx.edu. 
Discursive Security:

F.B.I. Stings and the Nature of Peace

by

Adam Testerman

A thesis submitted in partial fulfillment of the requirements for the degree of

Master of Science

in

Communication

Thesis Committee:

Cynthia-Lou Coleman, Chair

Priya Kapoor

Tanya Romaniuk

Portland State University

2015 


\begin{abstract}
The current study utilizes Critical Discourse Analysis and Thematic Analysis to study newspaper coverage of F.B.I. sting operations in The New York Times, Washington Post, and USA Today. F.B.I. sting operations are a modern counter-terrorism policy designed to preempt acts of terrorism. This study develops a theoretical approach to understanding F.B.I. sting operations by reviewing the critique of security. The critique of security suggests that nations construct threats in order to produce and maintain ideological and practical hegemony. Thematic categories of the newspaper discourse are formulated and analyzed in the context of security. The study employs aspects of grounded theory for theoretical positioning.

Findings suggest newspaper coverage of F.B.I. sting operations reflect and expand security in a number of important ways. Newspaper coverage provides information on a significant tactic used in the War on Terrorism and gives insight to the justification and reasoning for using that tactic. These pieces of information explain the interplay of security and counter-terrorism policy. However, findings also suggest security fosters positive relationships between nations, which requires repositioning aspects of the critique of security developed previously. Finally, newspaper discourse of F.B.I. sting operations helps contextualize the way modern counter-terrorism policy is ideologically configured. Findings show the dominant ideological configuration is security. The study considers how this framework contributes to a flawed understanding of the nature of peace.
\end{abstract}


Acknowledgments

I would like to thank all members of my thesis committee for guiding me in this project. Dr. Priya Kapoor gave me the opportunity to study this topic during my first year at Portland State University. Her insights and analyses of security and sting operations have gone a long way in helping me develop many of the ideas presented here. For her scholarship, friendship, and dedication, I am forever grateful. I also want to thank Dr. Cynthia Coleman for chairing my committee and helping me develop rigorous explications of theory. She is my mentor and friend. Finally, I am incredibly grateful to have worked with Dr. Tanya Romaniuk for this project. Dr. Romaniuk provided endless supplies of resources in helping me develop my methodological approach to this study. The dedication and scholarship of these three amazing women inspires me.

I also want to thank my friends and family for their support during the development of this work. My wife, Kathleen, and my dog, Bea, are the loves of my life. Thank you for everything.

Finally, I would like to thank Trevor Aaronson for his incredible scholarship in interrogating F.B.I. sting operations. His work guided this project from the very beginning. In a world where critical journalism is increasingly difficult to find, Aaronson's work sets the standard for excellence. 
Table of Contents

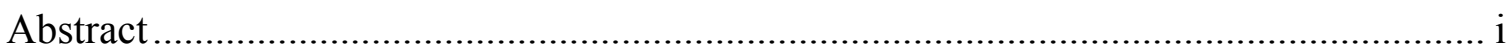

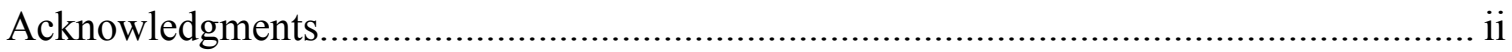

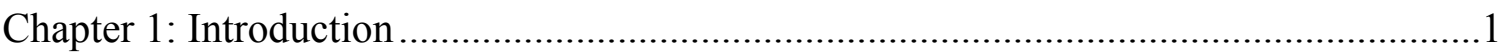

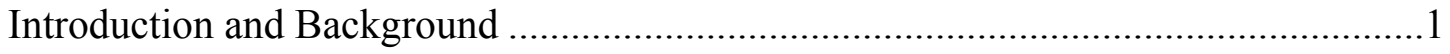

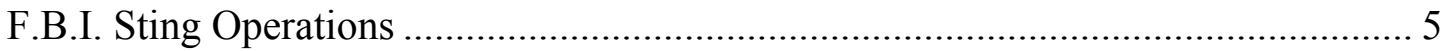

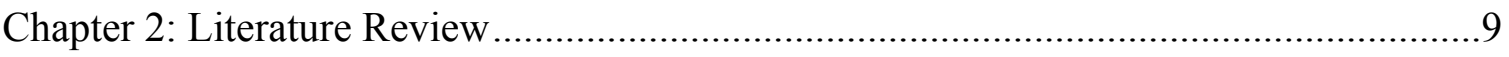

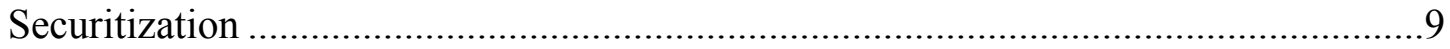

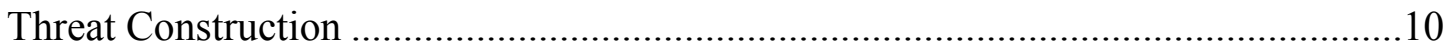

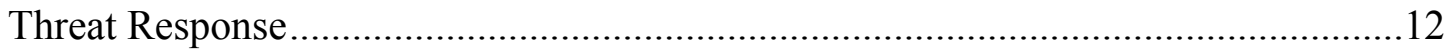

Contingent Legal Structures and the State of Exception ........................................14

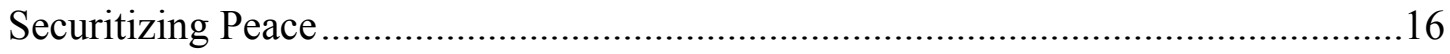

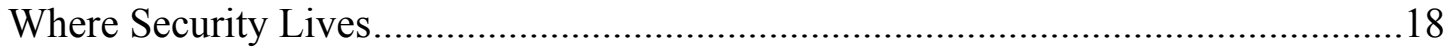

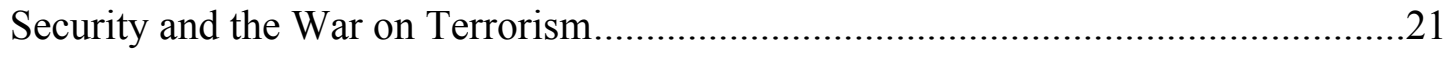

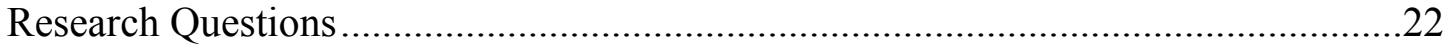

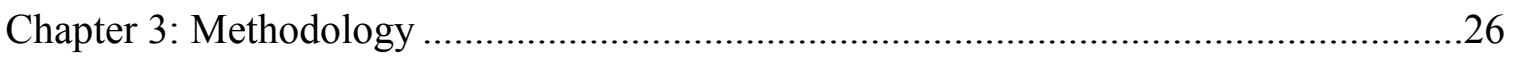

Analytical Framework: Critical Discourse Analysis ..........................................26

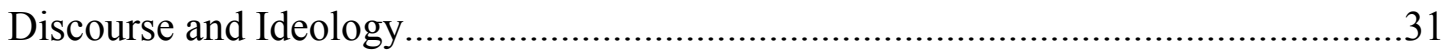

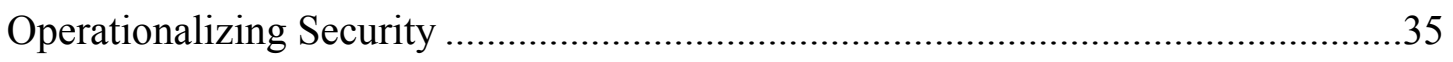

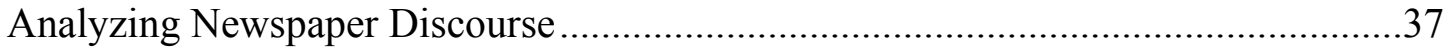

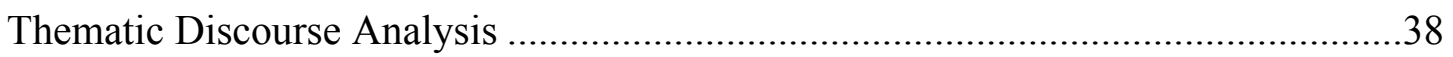

The Process of CDA with Thematic Analysis .........................................................41 
Procedures: Sample Size, Saturation, and

Procedures: Sample Size, Saturation, and Limitations .........................................46

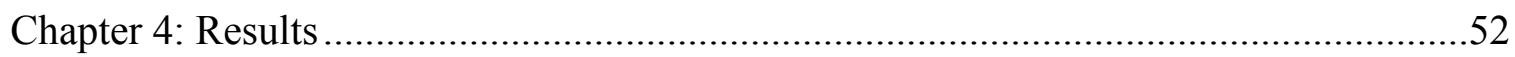

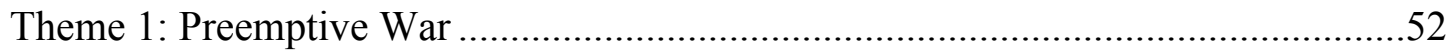

Theme 2: Informants................................................... 59

Theme 3: Cooperative Security........................................66

Theme 4: Stings and the Law ................................................ 72

Theme 5: Ordinary Targets and Dramatic Attacks............................ 78

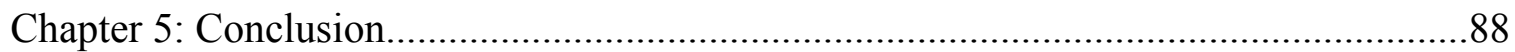

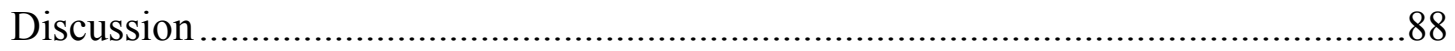

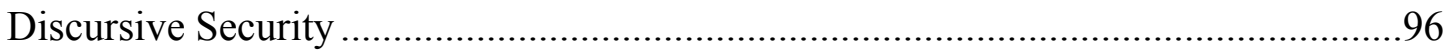

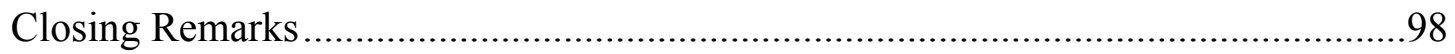

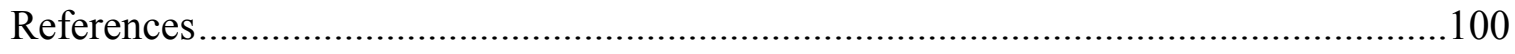

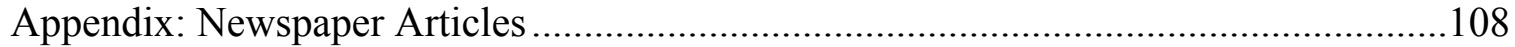


Chapter 1: Introduction

\section{Introduction and Background}

"In the wake of September 11, this aggressive, proactive, and preventative course is the only acceptable response from a department of government charged with enforcing our laws and protecting the American people. Awaiting an attack is not an option. That is why the Department of Justice is doing everything in its power to identify risks to our Nation's security at the earliest stage possible and to respond with forward-leaning- preventative- prosecutions"

-Deputy Attorney General Paul McNulty, 2006 (as cited in Sherman, 2009).

I first encountered the topic of F.B.I. sting operations in researching the case of Mohammed Mohamud. Mohamud was a 17-year-old Somali immigrant arrested for attempting to detonate a weapon of mass destruction in downtown Portland, Oregon in 2010. It was shocking for me to think someone attempted an act of terrorism in Portland; a city with few obvious connections to the War on Terrorism. I found it alarming that an act of such extreme violence was attempted by someone so young and at a holiday ceremony, where thousands of people could have been killed or injured. As I investigated the story further, it became clear that the case was much more complicated than I initially assumed. Mohamud did not plan the attack on his own; he had been made a target of a F.B.I. sting operation for over two years.

Federal agents were made aware of Mohamud through his online activity in Internet forums related to extremism. As Mohamud's interest grew in what he considered a noble struggle against U.S. imperialism, federal agents became increasingly convinced of his desire to commit acts of violence. Kapoor, Brehm, and Testerman (2014) investigate the War on Terrorism in mediated contexts and how it is discursively 
represented in news and entertainment media. Under the supervision of Dr. Kapoor, I assisted in analyzing local newspaper coverage of Mohammed Mohamud. I sifted through newspaper articles related to Mohamud's case. It became clear that there was general disagreement about the extent to which F.B.I. agents had directed Mohamud's path to commit violence. It did not seem clear that the F.B.I. had intervened to prevent an imminent attack: rather, it seemed likely the F.B.I. had guided and aided in the planning of the attack. This case was close to home. It was about the community I lived in (Kapoor et al., 2014).

This initial research led me to Trevor Aaronson's (2013) book The Terror Factory. Aaronson (2013) describes a recent, yet essential change in the way the U.S. government fights terrorism. This work analyzes F.B.I. sting operations conducted as part of the War on Terrorism. In these operations, government agents encounter individuals with "extremist" views and guide them to attempt to commit acts of terrorism. Federal agents claim they select sting targets on the basis of threat level. Individuals demonstrating willingness to commits acts of terrorist violence are recorded and monitored by government operatives for long periods of time as part of the sting process. Through the use of informants and undercover agents, the F.B.I. builds cases against these people based on a belief that they are preventing acts of terrorism from occurring. Based on Aaronson's work, it was surprising to learn that the case of Mohamud was not an isolated incident; rather, sting operations are common F.B.I. practice. Stings have been used in various police operations for decades; however, the use of stings has become a primary feature of the new ways the U.S. conducts the War on Terrorism. 
Individuals targeted in sting operations do not carry out acts of terrorism because the operation is constructed and guided by government agents. Federal agents help sting targets build fake explosive devices and arrest them moments after recruits attempt to detonate an explosion. Aaronson (2013) offers a scathing critique of such practices through disputing truth claims that these individuals were prevented from committing acts of violence rather than provoked to attempt such actions. Aaronson's (2013) work offers evidence that individuals captured in F.B.I. sting operations were guided to acts of violence they would never have perpetrated had they not been intercepted. While the government denies those claims and has secured numerous successful prosecutions against such a defense, the implications of the charges require further examination.

This study offers a few unique observations to the field of Communication. I draw on the principles of Critical Discourse Analysis to develop an analytic framework for analyzing media discourse pertaining to F.B.I. sting operations. This work is useful in extending our knowledge of newspaper coverage of the War on Terrorism by accounting for an important development within it. This work also offers an opportunity to show the ways thematic analysis can effectively position newspaper discourse with concern for theory. The central goal is to provide a comprehensive analysis of the main themes identified within newspaper representations of F.B.I. sting operations and position those themes for critical analysis.

My project expands on existing work in three ways. First, I will be able to further expand the critique of security by bringing it into the domain of Communication. While some scholars have developed critical interrogations of media coverage of the War on 
Terrorism, there has not been consistent application of previously developed theoretical models, such as the one that the critique of security offers. In this sense, my methodological approach to studying both the War on Terrorism and the critique of security is novel and potentially useful in guiding future research. Another important contribution my project offers lies in its ability to advance the critique of security at a theoretical level. Security studies of the War on Terrorism have primarily focused on external conflicts propagated by the United States. My project tracks the current trajectory of securitization in the War on Terrorism through consideration of emergent features.

Given Communication scholars' interest in the War on Terrorism in media discourse, it is valuable to understand media representations of new government counterterrorism tactics. Aaronson's (2013) work establishes the need for further examination from the field. This study is an attempt to account for discourse of F.B.I. sting operations. I adopt the principles of Critical Discourse Analysis and the methods of thematic analysis to identify and describe the major features of sting operations as presented in the New York Times, Washington Post, and USA Today. The goal is to make sense of this discourse at an ideological level, which requires not only a description of tactics, but a framework those tactics are situated within. One of the important tenets of Critical Discourse Analysis is to position discourse in relation to larger social relations. Investigating sting operations is not just a way to describe a tactic used in the War on Terrorism; it is also a way to understand how the U.S. understands the nature of violence and how to prevent it. 


\section{F.B.I. Sting Operations}

Law enforcement agencies have utilized sting operations as a tactic since their inception. Sting operations involve placing law enforcement agents within an investigation, such that officers participate in the activities of the criminal. Hay (2005) explains, "the defining feature of a sting operation is that through covert means, the authorities create or facilitate the very offense of which the defendant is convicted" ( $p$. 388). Sting operations have been the subject of numerous movies and novels, yet surprisingly little academic research exists on the subject. What does exist focuses on sting operations in contexts altogether different from those provided by Aaronson (2013). Sting operations have been written about in legal journals only, with attention paid to the legitimacy of their construct in a legal context (Hay, 2005; Sherman, 2009; Stevenson, 2008).

Using sting operations in counter-terrorism is a relatively new development. Sherman (2009) argues that President George W. Bush's decision to employ defensive counter-measures to fight terrorism was a necessary starting point. The use of informants were previously one of the main tools in the War on Drugs. As the War on Terrorism increasingly defines the parameters of U.S. security policy, features of previous security regimes seem inevitable. Legal challenges have been the only impediment to the use of stings.

The central legal question posed for F.B.I. sting operations concerns entrapment. Entrapment is the primary legal defense mounted by individuals charged of crimes in stings (Hay, 2005; Sherman, 2009). However, Aaronson (2013) notes that modern sting 
operations have been designed with the entrapment defense in mind. The U.S.

government's best way out of such a defense is its use of informants. Aaronson (2013)

notes,

“The F.B.I.'s use of informants today is unprecedented. In addition to the roster of 15,000 informants that the Bureau maintains - many of them tasked with infiltrating Muslim communities in the United States - for every officially listed, there are as many as three unofficial ones, known in F.B.I. parlance as 'hip pockets"” (p. 44).

Informants are used to provide first-hand testimony of a person's intent to commit an act of terrorism. These informants frequently have checkered criminal histories, which is how the F.B.I. is able to leverage their compliance with stings (Aaronson, 2013).

Another defining feature of F.B.I. sting operations is the consistent nature of who is targeted for investigation. Aaronson (2013) contends that F.B.I. sting operations primarily target young troubled Muslim men. Of the examples of operations contained in The Terror Factory, most involve people under the age of 25 who self-identify as Muslims. In many instances, acquaintances of sting targets were aware the person seemed withdrawn, troubled, and not themselves in the time leading up to and during the stings. According to Aaronson (2013), these operations seem to target people who may exhibit anti-social behavior, but frequently not those who have previously attempted acts of radicalism.

Aaronson (2013) contends that F.B.I. stings lead these people to attempt acts of violence that would be unlikely absent the intervention. While the legal standard for 
conviction requires the F.B.I. to prove otherwise, one need only look at the way laws are interpreted in legal journals to see the problem with such a standard. Stevenson (2008) argues, "terrorism is such a heinous crime that it is unlikely the government could induce someone to support such criminals unless the person was one of the few predisposed to do so" (p. 125). In a similar vein, Stevenson (2008) notes, "the difficulty of preventing terrorist acts and the civil liberties implications of intrusive surveillance- the alternative to stings- there should be a rebuttable presumption that anyone who provides material to support terrorism was predisposed to do so" (p.125). The formulation of legal reasoning displayed here suggests it is impossible to entrap a person for attempting an act of terrorism. Stevenson (2008) argues that no one could possible be led to terrorism because of the horrific nature of terrorist acts of violence.

This formulation will be proven problematic with the critique of security. It assumes that the only possible government intervention in the lives of troubled people with an interest in violence is to incarcerate them by leading them to commit acts of violence. The argument also assumes the only alternative to sting operations is mass surveillance. Either way, the state is given presumed power to enact any form of counterterrorism policy. It is also worth noting how legal reasoning sees surveillance as civil rights abuse, but says nothing as to the civil rights of people arrested in sting operations. It is also highly questionable to assume that stings are used as an alternative to surveillance; there is ample evidence to suggest stings accompany/coincide with dramatic escalations in the surveillance capabilities of government agencies. 
Sting operations are self-serving for the F.B.I.. They demonstrate a need for government action (constructed by the F.B.I.), an ability for the F.B.I. to effectively intervene (how could they not when they are the one's planning and building false bombs), and move the threat of terrorism to the domestic front. No longer does the government prioritize preemptive interventions abroad; now the policy of preemption targets people living in the United States. The bodies are the same; brown, Muslim, vulnerable... the tactics have shifted. 
Chapter 2: Literature Review

\section{Securitization}

One of the most important works in the development of security studies is David Campbell's (1992) book Writing Security. Campbell (1992) explains one of the central ideas behind security with the quote: "Danger is not an objective condition." (p. 1). A state is the governing power of a land mass. State identification of security threats does not take place in an ideological vacuum. A state identifying danger is not the same as other evaluations of risk. For example, if a government agency were to test a patch of land for the likelihood of an earthquake, the assessment of danger would necessarily be rooted in an objective evaluation of tectonic plates. When a state identifies dangers to itself in the form of other states or humans, these conditions never rely on purely scientific assessments of what constitutes danger (Campbell, 1992; Der Derian, 2002, 2003, 2008, 2009).

A state selects and identifies risks in relation to its own schema of world order. Campbell (1992) clarifies further: "Danger bears no essential, necessary, or unproblematic relation to the action or event from which it is said to derive. Nothing is intrinsically more dangerous for insurance technology than anything else, excepted when interpreted as such.” (p. 2). The insurance metaphor is useful here. Insurance companies set interest rates in relation to the risk they agree to assume in coverage. To assess risk, insurance companies must establish conditions for what constitutes such risks. This process always involves interpretation of world events through a particular schema of risk. Similarly, states enact security policies through their own criteria of risk. 
While this does not seem like a particularly novel line of thought, many authors argue that it is often overlooked in considerations of policies related to the military, police, and other forms of government intervention. Most of the time, risk assessment is thought of as a neutral practice; neutral in the sense that a state knows that which to securitize against by studying the presence of organizations and nations that may seek to enact violence against it (Chomsky, 2003). However, the field of security studies builds compelling arguments for risk assessment as not some politically neutral enterprise, but as the most concrete way a state's ideological status is produced (Campbell, 1992;

Gorman, 2004; Johnson \& Russell, 2005; Neocleous, 2005; Noorani, 2005; Vultee, 2010; Walsh \& Barbara, 2006). Through identifying what elements of the world are a threat to it, the state also is defining what its central tendencies are.

Central tendencies are produced through policies and practices of repetition. This view changes our understanding of a state from a regime of governance over particular geography and instead allows us to understand them as ideological bodies (Butler, 2006; Campbell, 1992; Neal, 2008). A state is constituted by what it does and the various laws and practices contained within its structure. As such, to understand the nature of the state, one must consider the ways states define themselves in relation to other states (Butler, 2006). It is in this process that securitization offers a compelling point of contribution. To see how a state really understands itself, one should consider that which the state labels as "threats" and ask questions about what it means to be a threat.

\section{Threat Construction}


Threat construction is one of the central tenets of security studies. Threat construction describes how states decide which kinds of dangers are in need of being securitized against. Political context influences how threats are constructed. Campbell (1992) explains, "the objectification and externalization of danger that is central to contemporary assessments of security and politics in the post-cold war era need to be understood as an effect of political practices rather than the condition of their possibility" (p. 18). Threats do not exist apart from the political context that generates them. This clarifies the central tenet of the security critique, which holds that threat construction is an interplay of power politics. States and non-state actors become threats when they challenge the political power of other states. There exists no universal standard for what counts as dangerous.

Der Derian (1991) argues threat construction is exemplified by the discourse towards the U.S.S.R. during the Cold War. The USSR was described and acted against because the regime represented a threat of almost existential risk. It is through this analysis that many security authors describe nuclear securitization, which explores how the U.S. uses instances of nuclear warfare as the backbone for securitizing the public against outside threats. Falk (1991) is careful to include the maintenance of internal threat projection as a key feature of securitization. Securitization explains how the red scare became such an important element of domestic policymaking/social discourse during the Cold War. The U.S.S.R. was the dominant political challenger to the U.S. for decades in the Cold War. As the ideological schema of governance prioritized overcoming threats posed by the U.S.S.R., the boundaries of what constituted such 
threats were continually expanded. The result was a search for tangential support for Communism or the U.S.S.R. among U.S. citizens. The nature of the threats posed by the U.S.S.R. gave the government nearly unlimited power to circumvent the rights of citizens in search for would-be sympathizers.

Threat construction is also an important feature of the War on Terrorism, which represents an incarnation of the security regime (Chomsky, 2003; Vultee, 2010). The War on Terrorism not only helps us understand how threat construction is worked out in government policy, but also presents the locus point of the critique of security. Chomsky (2003) asks us to question the nature of terrorism by showing how the policy actions taken by the United States to fight it actually amount to terrorism. In constructing threats, the United States is able to endlessly justify the actions it takes to stop it. Chomsky (2003) explains that the United States enabled many dictators to maintain positions of power in Latin America under the guise of the security framework. In Nicaragua, the U.S. directly enabled massacres of civilian populations so that the regime they supported could corner political power. In doing so, the U.S. could argue that it was safer from the threat of terrorism, while itself supporting policies that constitute terrorism.

\section{Threat Response}

Processes of threat construction establish nearly limitless military responses to threats. Der Derian $(2002,2008,2009)$ sees security as the framework that produces what he identifies as virtuous war. Virtuous war is always justifiable and is increasingly sanitized through virtual representation. Most people experience war in mediated 
contexts. Citizens watch news reports and soldiers operate drone strikes through video monitors hundreds of miles away from the violence. Because the experience of war is increasingly virtual, the conditions that justify war are constructed apart from the violence they inevitably justify (Campbell, 1992; Der Derian, 2002, 2003, 2008, 2009). This is where security discourse explains how threat responses are formed.

The response to threats is inevitably aligned with militaristic tendencies in the security framework (Campbell, 1992; Gorman, 2004; Johnson 2005; Neocleous, 2005; Noorani, 2005; Vultee, 2010; Walsh and Barbara, 2006). As previously noted, securitized states see threats as looming inevitabilities. There is always something to be found in the world that can be seen as dangerous. Multiple authors describe security states as paranoid because of these tendencies (Campbell, 1992; Der Derian, 2002, 2003, 2008, 2009; Dillon, 2008). The security framework produces solutions to danger that equal the paranoia attached to those threats (Neocleous, 2005; Noorani, 2005). The response to threats is to ramp up military machinery and display force.

As threats are deemed worthy of military engagement, the conditions for the use of violence become increasingly relaxed. Dillon (2008) argues that threat construction is in service of a deeply militarized world. Governments increasingly rely on the machinery of death to maintain a peaceful world order. Numerous theories related to blowback demonstrate the problems with this line of thinking. Governments engaging in violence to suppress danger tend to produce the very conditions that those risks originated in from the first place (Dillon, 2008; Neal, 2008). Iraq, for example, was positioned as an immediate threat to Middle Eastern regional stability prior to U.S. intervention in 2002. 
After years of intervention, it now is the locus point for I.S.I.S. recruitment and the cycle begins anew. In this way, the responses made to threats in a system of security produce a world that is fundamentally incapable of achieving peace (Cuomo, 1996). A recent article shows the cost of such frameworks. The War on Terrorism has led to the deaths of at least 1.3 million people worldwide (Carasik, 2015). Millions more have been displaced and/or victims of severe human rights abuses. The rhetoric of security prioritizes meetings violent threats with violence.

\section{Contingent Legal Structures and the State of Exception}

The critique of security is useful in conceptualizing the nature of the state. Agamben's (1995) conceptualization of exception helps to position a critique of security in a larger theoretical understanding of the state. The state is defined by its ability to suspend law at any moment; it is the state's defining feature (Agamben, 1995). One might assume the presence of laws and bureaucracy act as an internal restraint for how a state conducts itself. However, the legitimacy of these internal restraints is not a given. Every state is constructed on principles that also suggest when laws may be removed or suspended. States of emergency can be declared in times of disaster such that there are no longer any internal restraints on what a state can do. Agamben $(1995,2002)$ argues that the modern security state is increasingly defined by the tendency to make exceptions to law, than to be tied to its legal proscription. Agamben (2002) notes, "Today we are facing extreme and most dangerous developments of this paradigm of security. In the course of gradual neutralization of politics and the progressive surrender of traditional tasks of the state, security imposes itself as the basic principle of state activity" (p. 1). 
Understanding security as a central organizing concept for politics necessarily suggests the importance of describing and understanding it.

Agamben (1995) uses Nazi Germany to identify the ultimate state of exception; the Nazi's never overturned the constitution of the previous regime, but suspended it every four years to justify the various forms of control and murder they wished to pursue. The result was placement of bodies in concentration camps. There was never an ability for groups to challenge concentration camps on legal grounds, because law was not active; law was suspended in the name of security. The state's ability to determine legal norms and suspend them at any moment gives one reason to believe that all legal norms are inherently contingent. Legal norms are contingent on the state's decision of usefulness; when legal norms or rights rub against the state's desire to enact power, they are suspended or rewritten.

The critique of security is one way the US represents a state of exception. Many authors show how the US suspends its adherence to international law to justify various military interventions throughout the world (Chomsky, 2003; Vultee, 2001; Walsh \& Barbara, 2006). Of course it does this domestically as well. Muslim citizens have been the subject of intense surveillance, interference, and control by the state (Eid \& Karim, 2011). It carries then, that rights and protections are enshrined in exception. Security discourse ties these elements together. States produce security discourse to enable a state of exception. The risks associated with danger are able to make all legal norms contingent on their ability to prevent risk. Unfortunately, risk calculation takes place in ideological spaces. As such, legal norms are only a question of who has control of the 
reins of state power. As the modern state increasingly concerns itself with preventing the spread of violent Islam, we can anticipate all legal norms surrounding the legitimacy of intervention to be made contingent in relation to their ability to aid that quest. As we move into the very concrete ways security discourse is woven into the fabric of the War on Terrorism, it will remain important to keep Agamben's central idea in mind. The War on Terrorism takes place in a state of exception and is maintained through security discourse.

\section{Securitizing Peace}

Elements of the critique of security have been developed in the context of conflict resolution. Galtung (1969) is credited for developing positive peace theory. Positive peace theory suggests that a central problem with the way states engage in security is the limited scope of alternatives to violence and disorder they allow to be made available (Grewal, 2003). Cuomo (2006) argues that the result is a conflation of peace and violence. Peace is made into an empty signifier. It refers to nothing that one would think to associate with peace.

It is useful to consider the dimensions of positive and negative peace. Positive peace is about the promotion of sustainable solutions to conflict (Cuomo, 2006; Galtung, 1969; Grewal, 2003; Murakami, Kawamura \& Chiba, 2005). Positive peace requires us to see peace as more than the absence of violence; peace is reconfigured as the promotion of social justice and equality. Negative peace operates in the opposite way. Negative peace framing never attempts to find the root cause of problems; it only allows reaction to the byproducts (Murakami, Kawamura \& Chiba, 2005). In a system of a negative 
peace, something like terrorism is only made coherent as responding to and/or quelling extremist groups. Such a framework would never allow questions about why people are motivated to engage in acts of terrorism nor would it seek to address those conditions.

Security positions peace studies in similar ways that positive peace theorists have suggested. A world viewed through the lens of security is unable to meaningfully address social justice issues. Instead of building a framework of care and understanding, security remains wrapped up in a mindset of realism. Realism is the defining political theory of the modern age. It suggests that the world is inherently structured through competition (Murakami, Kawamura \& Chiba, 2005). Realism argues that nations are always vying for power and influence, and as such, every action is ultimately framed as a question of how strategically beneficial it can be according to an individual nation's limited self-interest (Chomsky, 2003; Cuomo, 2006). It is clear that security and realism are close cousins. They share similar epistemological foundations. Both frameworks assume nation's project threats according to their ideological foundations and seek aggressive military solutions to those threats as a result.

Positive peace theory can be read as a theoretical answer to security. Positive peace theorists are significantly more concerned with the ethics of care than they are with understanding when violence is permissible. Positive peace suggests that most violent conflicts and strategies arise not from the inevitability of other nations/actor hegemonic self-interest, but as reactions to a system structured to promote violence (Cuomo, 2006; Galtung, 1969; Grewal, 2003; Murakami, Kawamura \& Chiba, 2005). Many would suggest the issue of terrorism reflects a deeper concern than facilitating acts of terrorist 
violence. Terrorism occurs because groups of people are subjugated in various ways: politically, economically, socially (Chomsky, 2003; Cuomo, 2006). Positive peace sees peace not as the absence of violence, but as the promotion of stability, equality, and health. Advocates see these qualities as necessary to avoiding the securitization mindset and finding ethical solutions to the conditions that produce violence.

\section{Where Security Lives}

The literature surrounding the field of security discourse represents a variety of epistemologies. Security discourse covers a wide range of materials that discuss the implications of the current US strategy for maintenance of international peace. Political scientists have tended to focus on the specific policies and apparatuses of security (Kapoor et al., 2014). Others approach the discourse from a philosophical perspective focusing more on the ethical implications of security framing. Both approaches are useful in understanding security discourse from different perspectives.

The political science approach to security discourse understands it as the policies passed for the goal of preventing violence. This is an extremely broad framing, but emerges from the discourse surrounding the War on Terrorism (Straw, 2007). Security discourse in this field explores the specific ways that policies are framed around the goal of maintaining global peace. Research examines the specific justifications for different actions in the War on Terrorism, and attempt to frame those justifications around a larger concept of US interventions (Brown, 2004; Gorman, 2004; Johnson \& Russell, 2005). Some research framed around the War on Terrorism compared the concept of security 
discourse to specific concepts of Executive power and International law (Arnold, 2006; Owens, 2006.)

Political science approaches to security focus on US policies in the Middle East. The US takeover of Iraq is framed around the need to maintain global peace in many articles (Fried, 2005; Kaplan, 2010; Leaman, 2004). Other research explored similar themes in their coverage of the US intervention of Afghanistan (Sanger, 2009). Recent development with US policy in the Arab Spring has also seen some comparisons to the field of security discourse (Burns \& Price, 2013; Busch \& Pilat, 2013; Morey, Thyne, Hayden, \& Senters, 2012). This research positions the specific policies in these regions around the larger frame of security discourse. The authors sketch a picture of US security that prioritizes military interventions in sovereign nations, often without the pretense of international law as a justification.

The philosophical approach to security discourse is well established. Drawing on the work of Michel Foucault $(1972,2004)$, many authors see the field of security in terms of biopower, which describes how life is dictated by political calculus (Crampton, 2010; Dillon, 2008; Evans, 2010). Security is the state's ability to maintain and control populations not only through discourse, but also through the use of extreme violence. Biopower is constituted not just by the actual deployment of military forces, but by the ability to control the framing and rhetoric surrounding those issues (Crampton, 2010; Dillon, 2008; Evans, 2010; Neocleous, 2008). Another aspect of the philosophical approach to security is the view that security is socially constructed. This research suggests that security is not an objective state of affairs that countries respond to, but that 
security is created and managed through social discourse (Campbell, 1992;

Karampampas, 2009).

Another philosophical discourse around security frames it in the modern psychoanalytic tradition. Writers suggest security discourse is a product of modern imagination, in the sense that it is created as a guise for the advancement of bourgeoisies interests (Conley, 2010; Maggio, 2007; Zizek, 2002, 2011). These scholars understand security discourse not just as a relationship of power and domination, but also of one that captivates the American public. Security is something done to the population, but also something they participate in and benefit from by virtue of their privileged world standing. These views see security as an ideological campaign, marked not by the advancement of peace and stability so much as the advancement of Western capital interests.

Communication scholars have studied many aspects of security. To make this claim requires positioning their research in light of the security literature, because they rarely explicitly state a relation with the field of security. The critique of security provides a theoretical guide for media studies of terrorism. Security explains why researchers like Iguarta and Cheng (2009) find that media frames emphasizing "crime" are particularly powerful in producing cognitive responses. Not all frames produce the same effects. There is something unique about stories that identify "safety" concerns as a reason/implication of their discourse. Security gives us the ability to position those kinds of frames with theory. Security is "used" and "produced" by the state for reasons. Government officials understand the power of security and as such, those frames are used 
when public support needs to be navigated in order to pursue various militaristic policies. This view lets us see security as a media effect.

\section{Security and the War on Terrorism}

The War on Terrorism is another production of the security state. This is clear from a brief consideration of the policy features of the War on Terrorism (Vultee, 2010, Walsh \& Barbara, 2006). The War on Terrorism is indeterminable; it has no particular features that allow it to be clearly identified in either discourse or policymaking. Any conflict the state encounters can be identified as a part of the War on Terrorism. It is a conceptual schema that produces securitization as a defining feature of government policy. The War on Terrorism is the backdrop of numerous interventions by the US. Both domestic policing of citizens and interventions abroad constitute the domain of the War on Terrorism discourse. Threat construction carries an implicit justification for any action to be taken because the risks always merit such action. Intervention in Iraq is necessary because the threat of nuclear proliferation and support of terrorist networks is the most important element to be guarded against. Of course, this rhetoric echoes many of the features of the Cold War. Threats are over-stated and manipulated by government elites so that they can enact any policy deemed useful in securing state power, most often in the form of resource acquisition and military basing (Chomsky, 2003).

The War on Terrorism is a regime of security in the ways it is discursively constructed. Security scholars point to the ways threats are positioned with War on Terrorism discourse (Vultee, 2010). The state projects threats in nearly every political situation involving terrorism (Der Derian, 2008). Countless speeches from government 
officials insist on the looming threats posed by Al Qaeda and other terrorist organizations (Neocleous, 2008). War on Terrorism discourse builds a justification for the escalation of militaristic intervention and circumvention of any/all established legal norms (Agamben, 2002; Arnold, 2006; Balzacq, 2010; Conley 2010; Dillon, 2008). The analysis presented in this study offers demonstrates the ideological configuration of the War on Terrorism. However, a brief consideration of its defining features builds a sufficient case for the application of security literature to the analysis of media discourse on F.B.I. sting operations.

News media lead people to see terrorism as separate from the state. The state cannot commit acts of terrorism. Chomsky (2003) and Eid and Karim (2011) point out the false dichotomy and the ultimate lack of meaning in demarcating acts of violence by a nation-state. Nations can and do commit acts of terrorism. The critique of security helps us understand why people lack the desire and/or ability to critique states; while violence may be equivalent, the state carries a form of legitimacy with the acts of violence it perpetrates. This fits with Agamben's argument about the state of exception. The state is immune to criticism because it constructs its own schema of legitimacy.

\section{Research Questions}

Several research questions emerge from an overview of F.B.I. sting operations and the critique of security. This project asks ideological questions of F.B.I. sting operations. I begin with an understanding of security to guide my interactions with newspaper discourse. In drawing out the discursive themes of sting operations, I aim to 
show their relationship with security. This allows me to establish three major research questions for this project:

Research question one is: What are the prevailing themes in national newspaper coverage of F.B.I. sting operations?

Research question two is: In the context of national news coverage of F.B.I. sting operations and the War on Terror, what are the prevailing themes concerning security? By establishing several clear conceptual categories related to security, I aim to see the ways newspaper discourse interacts with previously established literature on security.

Research question three is: How does newspaper discourse of F.B.I. sting operations omit alternative interpretations of threat construction or discursive constructions of threat response? Asking a question of subjugated discourse requires prior knowledge about the ideological configuration of security policy, especially as it would relate to F.B.I. sting operations.

My analysis seeks to identify the prevailing themes of the dominant discourse, but remains aware of the ways alternative discourses are obfuscated. The foundations of security are captured in the major conceptual categories: threat construction, aggressive responses to threats, contingent legal structures, peace securitization, and terrorism discourse. These categories combine to form the critique of security. We are left with the task of putting those categories to work, by determining where the discourse they assume can actually be located.

Previous literature establishes discourse related to the War on Terrorism as necessarily tied to the framework of security. One need only consider the 
epistemological foundations of the War on Terrorism to make such a case. The War on Terrorism has always focused on preemption as a central organizing concept. The Bush Doctrine is the stated policy of the War on Terrorism, and it holds that the US will militarily engage nations who support terrorism and will do so preemptively if evidence suggests the possibility of threats.

Currently, the criteria for determining when a nation is sponsoring terrorism are poorly defined (Chomsky, 2003; Eid \& Karim, 2011). Many argue such designations are merely reflective of the security paradigm. That is, the level of support of terrorism is not measured with objective criteria shared by all nations. Instead, nations that support terrorism are those that stand in opposition to the goals of the West. For this reason, Israel is not a state-sponsor of terrorism but Iran is. Both countries funnel money to nonstate actors and both have been directly linked to human rights abuses including the refusal to participate in international legal frameworks (Chomsky, 2003). However, Israel is a strategic ally for the US and so the acts of violence it supports and enacts are judged by different criteria. Different criteria exist for allies of the powerful.

The critique of security offers necessary conceptual positioning for sting operations. Security refers to the ways nation states understand and respond to threats. Threats are the embodiment of danger. Dangers and risks do not exist in vacuums; they have to be recognized, identified, and constructed by people. Security is an attempt to explain how nations practice the construction of threats. In identifying threats, nations also build what they understand to be the necessary responses to those threats. The threat identification process is ideological. 
Ideology is the framework of understanding from a particular perspective. It is a filter placed on the world that allows the world to be seen from a particular point of view. From one perspective, F.B.I. sting operations are a useful way of addressing a dangerous problem, terrorism. From another perspective, sting operations reflect aggressive responses to unlikely threats. Both perspectives are ideological, but with different filters. They are ideological because they approach the same question with different conclusions stemming from a larger way of understanding the world. If one assumes the legitimacy of militarily engaging dangerous enemies, sting operations are justified. If one assumes terrorism requires meaningful engagement to solve, sting operations are problematic. Security describes the ideology of safety. Security scholars ask questions like: What counts as dangerous and why? Who benefits from the way danger is constructed? How does the construction of danger contribute to the way the West responds to threats? These are ideological questions; they seek to unmask the logic behind risk assessment and response. 
Chapter 3: Methodology

\section{Critical Discourse Analysis}

Fairclough and Wodak (1997) outline the eight major features of Critical

Discourse Analysis. They argue:

"[1] CDA addresses social problems;

[2] Power relations are discursive;

[3] Discourse constitutes society and culture;

[4] Discourse does ideological work;

[5] Discourse is historical;

[6] The link between text and society is mediated;

[7] Discourse analysis is interpretative and explanatory and

[8] Discourse is a form of social action" (as cited in Scollon, 2001, p. 141).

These features appear in slightly different articulations throughout the literature on Critical Discourse Analysis (Cameron, 2001; Cameron and Panovich, 2014; Simpson and Mayr, 2010; van Dijk 1995, 2006; Wodak and Meyer, 2009). I will briefly discuss the significant dimensions of each criteria in turn.

Critical Discourse Analysis addresses social problems and builds a discursive understanding of power. Social problems are never easily defined within the locus of Critical Discourse Analysis studies; it depends on the standpoint of the researcher and previous literature to argue for a particular artifact as representing a social problem. This study addresses a social problem; the problematic construction of counter-terrorism policies Critical Discourse Analysis is much less concerned with describing the world than it is with rooting out and addressing problems with in it. This is far too simplistic of a characterization, because one must be able to describe the world concretely in order to say what is wrong with it. However, from a research standpoint, it is taken as a given in 
Critical Discourse Analysis that the endpoint of a study should point to a corrective mechanism (Fairclough, 2013a, 2013b; Fairclough and Wodak, 1997; Simpson \& Mayr, 2010; van Dijk, 1995, 2006). Critical Discourse Analysis studies imply the need for social change. This is not necessarily assumed in other methodologies; scholars in other paradigms may assume corrective measures are implied in their analysis, but they do not take it is a guiding principle of their research. The current project points to social change in the form of adopting positive peace theory to understand and respond to terrorism.

Power relations are necessarily discursive. Power refers to the ability to control and guide the exchange of meaning. Similar to Gramsci's conceptualization of hegemony, Critical Discourse Analysis understands power as both physical displays of coercion and maintenance of consent from those controlled. In the current study, power relations are questioned in the form of government response to terrorism. Critical Discourse Analysis is concerned with the ways power is inscribed and produced within texts (Fairclough, 2013b). Critical Discourse Analysis scholars take as a metatheoretical assumption, that knowledge and reality are mediated by power relations (Fairclough, 2013a, 2013b; Fairclough and Wodak, 1997; Simpson \& Mayr, 2010; van Dijk, 1995, 2006). Hegemony is the term given to the dominant social formation or ideology; it is the perspective of power that seeks to normalize and control alternative discursive formulations. Because power is constituted through maintenance of ideological hegemony, it is necessary to evaluate the mechanisms through which ideology is spread. Gramsci (1996) maintains that ideology is embedded within all structures of society, 
including entertainment and media. Critical Discourse Analysis research provides a methodological scheme to identify and criticize ideologies present in discourse.

A Critical Discourse analytic framework views discourse as constituting the world around us. It embodies and constitutes our reality. Discourse is a difficult concept to define, but it generally refers to the various ways meaning is communicated (Simpson \& Mayr, 2010). Meaning is communication through speeches, newspapers, television programs, and conversations, which are all forms of discourse. Critical Discourse Analysis scholars believe that these various forms of discourse tell us about how society functions in both practical and ideological terms. Fairclough (2013a, 2013b) separates micro and macro level discourse to make this argument. Micro-level discourse refers to instances; that is the individual texts under investigation; macro-level discourse is the total product of ideologically related instances. A locus of newspaper articles is an instance of a discourse; it is not the entire discursive situation related to the subject under study. This means it is possible to map specific instances of discourse contextually; to say something about society by saying something about newspaper representations of society. It also works in the opposite direction; larger social formations necessarily position instances of discourse. In this view, one can analyze texts from prevailing themes to lexical and/or grammatical choices and in that process say something about macro-level Discourses.

Gee (2007) distinguishes discourse (with a small “d”) as language in use and Discourse (with a capital "D") that connects language with social practices. Gee's (2007) argument suggests that society is comprised of many discourses and constituted by them. 
These discourses are the various sites of meaning exchange, such as television programs, conversations citizens have with one another, and even newspaper texts. Gee's (2007) formulation of "d" vs. "D" discourse is another way of characterizing the relationship between micro and macro level discourses. One can speak of the domestic discourse of the War on Terrorism but also alternative discourses which can be (re)produced in texts. Relevant to the theoretical positioning of Critical Discourse Analysis is consideration not just of what discourse is present, but what is left out. The dominant discourse is established through repetition or saliency across articles. Subjugated discourses (not mentioned or obfuscated) are possible interpretations of the news subject that are left unrepresented in the data. My research style involves analyzing discourse in the form of national newspaper coverage of F.B.I. sting operations, to say something a larger social Discourse namely, security. Sting operations are only one component of this larger Discourse; however, the analysis will reveal how stings are particularly illustrative of that Discourse.

Connecting discourse with social reality is a central aim of Critical Discourse Analysis. The way stories are constructed within texts reflects both the historical and ideological practices of a nation. Discourse does not operate in a vacuum; it is influenced by, and in turn influences, society and social structures (Fairclough, 2013a, 2013b; Fairclough and Wodak, 1997; Simpson \& Mayr, 2010; van Dijk, 1995, 2006). Some scholars search for the ideological underpinnings of discourse within linguistics (Cameron, 2001; Ehrlich \& Romaniuk, 2014; Fairclough, 2013a, 2013b; Fairclough and Wodak, 1997; Simpson \& Mayr, 2010). Others are more concerned with the ways texts 
as a whole are positioned to guide particular ideological mappings (van Dijk, 1995, 2006; Wodak \& Meyer, 2009). As the body of Critical Discourse Analysis literature expands, the approaches to discourse analysis have proliferated in many different configurations. As a method, Critical Discourse Analysis offers researchers flexibility in the way texts are analyzed. As long as evidentiary support can be explained and defended, researchers may position their investigations to suit the particular needs of the project.

Critical Discourse Analysis explains the relationship between text and social structures. Fairclough and Wodak (1997) explain that discourse is always positioned historically. A piece of discourse evokes history and is situated within it. People bring their previous knowledge to the table when encountering discourse, which means historical positioning is necessary when studying media texts. This study understands F.B.I. sting operation discourse in a contextual history as a part of the War on Terrorism. Newspaper discourse on stings would be difficult to understand absent this context. This also explains the other tenet of Critical Discourse Analysis, that text and society is mediated. There are intervening variables when people read text, such as the various things they already know about terrorism and related features. Cameron and Panovic (2014) explain that people encounter discourse with awareness of the relationship between the text they read and the texts they have read. They explain, "As readers, we are predisposed to treat adjacent chunks of language as if they were connected, and to make connections even when none were intended" which means "when we approach a text with a view to making sense of it, we not just consider its structural linguistic properties, we also refer to two others considerations: our background knowledge about 
the world outside the text, and we think the producer of the text might have intended to communicate" (2014, p. 5). This mediated relationship with texts and society requires researchers to situated texts historically and with consideration for the nature of mediation at work. This process is interpretive and explanatory because the researcher must assess and argue for the way texts are linked with society. This project utilizes thematic analysis to guide interpretation and explanation.

\section{Discourse and Ideology}

Two concepts that are central to Critical Discourse Analysis are discourse and ideology. Discourse is rarely constrained to one meaning. It refers to many different situations in which meaning is shared. Ehrlich and Romaniuk (2014) define discourse as "language embedded in social interaction" (p. 460). The authors acknowledge traditional conceptions of discourse as written sentences, but also give room to other understandings, such as discourse in the form of speeches and other forms of communication. To study discourse requires analysis of the words and phrases used to communicate an idea, but with consideration for context (Cameron \& Panovic, 2014). Discourse analysis involves "the mobilization of non-linguistic and contextual knowledge" (Ehrlich \& Romaniuk, 2014, p. 460). Thus, Discourse is more than just language above the level of the sentence; discourse is the incarnation of thoughts, beliefs, and understandings of the world (Cameron \& Panovic, 2014). To study discourse is to analyze language-in-context to make sense of a larger social context.

The work of Foucault $(1972,2004)$ is influential in characterizing the complex relationship between discourse, power and ideology. Ehrlich and Romaniuk (2014) and 
Kapoor et al. (2015) identify the importance of Foucault in conceiving of discourse. Kapoor et al. (2014) explain: "Power in the Foucauldian frame is not simply top-down but circulates through several channels and intermediary circuits in society all of which wield power in their own right" (p. 9). Power is the ability to define and direct knowledge. It is possible to locate power in various channels through which knowledges are transmitted (discourses). Foucault is influential in mapping one of the key foundations of Critical Discourse Analysis, which is the role of discourse and power. Foucault's understanding of power can be summarized in the following way: "power is exercised through discourses of knowledge... which functions to define and categorize, and, in turn, to regulate and control the objects of their expertise" (Ehrlich \& Romaniuk, 2014, p. 460). In these ways, studying discourse involves analyzing how power/knowledge are situated within communication.

To understand power requires an understanding of where "knowledge" is being negotiated and constructed. Critical Discourse Analysts use this understanding of power to situate their investigations of texts. Ehrlich and Romaniuk (2014) note that Critical Discourse Analysis "attempt[s] to show how the nitty-gritty details of socially situated linguistic interactions can be constitutive of social identities and social practices" (p. 461). Newspaper representations are one way that knowledge of social identities and practices are constructed; therefore, studying newspaper discourse enables commentary on such practices.

Emerging from analysis of texts are ideological configurations. Scholars investigating discourse are attempting to draw out the ways ideology is represented and 
positioning such representations in the context of power. Ideology is often defined to suit the needs of the researcher investigating it. For this reason, it is difficult to glean one particular meaning of the term. The classic Marxist conception of ideology describes how capitalist logic runs through and across all of the activities and structures of modern society (Eagleton, 1979). For example, a decision to attend school is in service of production. In this view, students are taught how to be good members of a functioning capitalist regime: knowledge production is thus ideological, it is geared toward the maintenance of a structure, even though this process is opaque and unrecognized by most of the people within the structure. Eagleton (1979) understands ideology as a way of describing and providing meaning to the practices groups of people engage in. He explains: "Ideology... is not to be reduced to a miscognition, but is to be seen as signifying a set of practical relations with the "real"' $(1979$, p. 63). While people do not necessarily recognize that the practices and actions they engage in are filtered and guided by a framework/filter of ideology, they nonetheless can be described and grouped in ideological terms.

Louis Althusser's (1971) work on state ideology provides an effective framework for understanding the modern security state. The modern security state is defined by its willingness to understand nearly any situation in terms of security (Agamben, 2002). Althusser (1971) explains Ideological State Apparatuses as the different forms of concentrated power as represented in the government and political institutions. Althusser (1971) writes: 
"not only does the State apparatus contribute generously to its own reproduction (the capitalist State contains political dynasties, military dynasties, etc.), but also and above all, the State apparatus secures by repression (from the most brutal physical force, via mere administrative commands and interdictions, to open and tacit censorship) the political conditions for the action of the Ideological State Apparatuses”(p. 9).

By understanding citizens as subjects of power, the state is able to advance hegemonic ideology, which serves the primary purpose of maintaining power relations. Integral to this idea is the concept of hailing the subject. Althusser (1971) suggests, "that ideology 'acts' or 'functions' in such a way that it 'recruits' subjects among the individuals (it recruits them all), or 'transforms' the individuals into subjects (it transforms them all) by that very precise operation which I have called interpellation or hailing” (p. 22). We must ask what kinds of roles the Ideological State Apparatus wishes for its citizens to occupy. In the War on Terrorism, ideology conditions state actions and its implications for precarious populations of citizens.

The current project uses these understandings of ideology and discourse as organizing principles. Analyzing newspapers for representations of security requires positioning text in a social context. I aim to understand not just how F.B.I. sting operations are described, but also how those descriptions reflect a particular ideological positioning. By placing discourse in an ideological formation, I necessarily show alternative ideological configurations. It becomes obvious that there is more than one way to understand and make sense of security dilemmas such as terrorism. Counter- 
terrorism efforts like sting operations are not an inherent part of social life; groups of people with certain ideological frameworks chose such approaches.

\section{Operationalizing Security}

To study F.B.I. sting operations in media requires establishing the conceptual categories related to security as something that can be identified in discourse. Previous research has thoroughly connected the critique of security with media discourse. Security is useful in describing and positioning discourse in a larger social context. The categories of security are robust, but they sometimes lack explicit criteria for what would count as evidence for their presence. Critical Discourse Analysis serves as an analytic framework for this project, while thematic analysis provides the methodology for analyzing specific texts.

Securitization exists as both discursive and in the form of social practice (Balzacq, 2010). The discursive form of security is produced through communication. The words and conceptual schema of security are identifiable through evaluating language choices and speeches of political leaders. Security discourse is also shared among citizens; it constitutes how people think and talk about issues (Campbell, 1992; Der Derian, 2002, 2008, 2009, Falk, 1991; Neocleous, 2008). The social practice of security is identifiable through government policies. In this view, security is operationalized less in the language used to describe things and more on the actions taken to "deal with" threats (Chomsky, 2003). Both the discourse and practice of security causes people and governments to construct threats. 
Operationalizing security is an important aspect of this study's methodology. Security will be argued for, rather than objectively constructed and deployed. I put security to work by analyzing newspaper discourse with concern for identifying the major features of security developed in my literature review. I will do this by analyzing the discourse collected in my sample. Because previous literature suggests individual words and phrases within discourse must be positioned contextually, with concern for larger social structures that they are circulated within and ultimately comprise, I will make the case for such configuration of my collected newspaper discourse. The literature review is structured in ways that attempt to take Chaffee (1991) seriously. That is, I attempt to explicate security according to its major theoretical foundations. This study is also about doing more concept explication. By drawing out the major discursive formations of media coverage of F.B.I. sting operations, I will attempt to show how security may be grounded. Grounding security is accomplished by attempting to answer the research questions. It requires understanding the major themes present in the data and then comparing those themes with the categories of security. This process opens space for addressing the final research question related to understanding alternative discursive constructions of F.B.I. sting operations. Thus, the research questions combine to "ground" security in empirical investigation.

A central question with my approach lies in the consideration of evidence. The study's ability to make a claim for a particular quote or phrasing constituting an element of security will have to be clearly explained and defended. A significant benefit to this particular investigation is the vast body of terrorism and security literature that has been 
previously developed. For example, Hodges (2011) writes in-depth about the significant discursive formations of Bush's War on Terrorism. These discursive formations serve as cues during data collection. For example, Hodges (2011) finds that War on Terrrosim discourses emphasize an us v. them dichotomy. Awareness of discursive features of the War on Terrorism developed in previous literature serves to guide the discovery of similar features in this project.

\section{Critical Discourse Analysis and Newspaper Discourse}

Many of the principles developed in Richardson's (2007) work guide my approach to analyzing newspaper discourse. Richardson's (2007) central argument is, "the sourcing and construct of the news is intimately linked with the actions and opinions of (usually powerful) social groups; it is impossible to select and compose news without a conception of the target or intended audience" (p. 1). Richardson (2007) considers the various ways newspaper discourse influences and reflects social realities. While multiple approaches are analyzed, Richardson's (2007) configuration for Critical Discourse Analysis studies of newspaper is illuminating for the scope of this investigation. Critical Discourse Analysis of newspaper content involves analyzing the ways texts are situated contextually. The process requires mapping theory from social life and using that knowledge to guide an interpretation of media text. Because ideology is embedded within discourse, the researcher must demonstrate in plain terms how sections of newspaper content are situated in ideological terms.

This study will make a case for the ideological configuration of security embedded within newspaper content. Richardson (2007) suggests several ways this can 
be accomplished. In discussing newspaper coverage of war, one might attend to the ways possibilities are constructed in newspaper text. If the claim is made in an article, via sourcing or otherwise, that inaction is not an option, the discourse could be said to narrow the discursive field of conflict to engagement. Such a conception may be in the service of established war practices utilized by government elites. Richardson (2007) ultimately asks scholars to carefully consider the ways discourse is formed within a news story and evaluate the way such constructions contribute to established ideological frameworks.

Security is an ideological framework that can be identified within newspaper discourse. Many of the examples of war narrative discourse that Critical Discourse Analysis scholars have previously researched could be argued in the context of security (Hodges, 2011; Richardson, 2007). This means my study will have the benefit of using previous research to focus which kinds of rhetorical constructions ought be considered. My study considers the categories of security developed above to accomplish contextual analysis of newspaper discourse.

This study investigates a micro-level discourse in the form of F.B.I. sting operations. I have attempted to make a case for F.B.I. stings as a necessary component of the macro-level discourse of terrorism. The critique of security is thus further clarified by drawing out greater depth of one its constitutive elements, terrorism. This means that even though the scope of my investigation can only speak to one element of discourse, it has the effect of multiplying understandings of larger points of reality. This project offers something valuable to what we know about other forms of discourse.

\section{Thematic Analysis}


Thematic analysis involves analyzing text with consideration of its most significant features and in relation to larger social groupings of thought. The process incorporates many of the foundational aspects of qualitative analysis including the desire to preserve meaning from the original text. Attride-Stirling (2001) describes the process of thematic analysis as, "a methodical systematization of textual data" which allows for "a sensitive, insightful, exploration of a text's overt structures and underlying patterns" (p. 386). Drawing on the grounded approach advanced by Corbin and Strauss (1990), thematic analysis involves the analysis of text in three stages: basic themes, organizing themes, and global themes.

Researchers begin textual analysis by searching for basic themes. Basic themes are those made salient in particular pieces of text. Basic themes are found by culling the significant elements of an individual article or part of an article; they are not yet organized into statements about a body of discourse, they are lower-level patterns that require further positioning in relation to a larger body of discourse. Basic themes are then translated into organizing themes. Organizing themes connect instances of salient features in broader groupings of thought. Organizing themes are "clusters of signification that summarize the principal assumptions of a group of basic themes" (Attride-Stirling, 2001, p. 389). The final stage of thematic analysis is the development of global themes. Global themes connect organizing themes together to "tell us what the texts as a whole are about within the context of a given analysis" (Attride-Stirling, 2001, p. 389). Global themes are the final conclusions established for a grouping of data in a study. 
Thematic analysis is iterative in nature. In order to move from basic themes to organizing themes, the researcher remains open to category reconfiguration throughout the research process. Themes are developed through close textual analysis and consideration of evidence across a body of text. Attride-Stirling (2001) clarifies the process: "Once a collection of Basic Themes has been derived, they are then classified according to the underlying story they are telling and these becomes the Organizing Themes. Organizing Themes are then reinterpreted in light of their Basic Themes, and are brought together to illustrate a single conclusion or super-ordinate themes that becomes the Global Theme" (p. 389). The central idea of thematic analysis is making connections between texts apparent in order to convey deeper meanings suggested by the texts.

This study combines the theoretical principles of Critical Discourse Analysis elaborated previously with Thematic Analysis. Critical Discourse Analysis provides researchers with the tools necessary to compare actual instances of little-d discourse with social structures to say something about capital-d Discourse. When readers encounter a story about a F.B.I. sting operation, they are also encountering a larger framework of discourse, the War on Terrorism. To make sense of F.B.I. sting operations requires consideration of both the way the text describes the tactic and also how those tactics are situated within the how the U.S. understands the issue of terrorism. Stings are not isolated in contextual space. To understand how texts about sting operations are situated within a larger discourse of the War on Terrorism requires interaction with relevant theory. 
The relevant theory explaining the interaction between F.B.I. sting operation discourse and War on Terrorism Discourse is security. Security authors note the ideological nature of the construct. There are not individual words that comprise security; security is found in the practice of threat prevention. This study builds on the basic tenets of security to guide the analysis, while the process of developing themes in the data leaves other aspects open to discovery. In this way this project represents a blended approach of Critical Discourse Analysis and Thematic Analysis. I incorporate the theoretical assumptions of Critical Discourse Analysis and the positioning of discourse with larger social formations but then focus on how patterns of textual evidence can be thematized, instead of focusing on the specific linguistic tools used to communicate and construct ideological meanings. This is because the project is aimed at drawing out the major discursive themes of newspaper coverage of F.B.I. sting operations and considering how those themes interact with and position research on security.

\section{The Process of CDA with Thematic Analysis}

Themes "emerge" from data through repetition, saliency, and emphasis.

Thematic analysis requires reformulating categories during the research process to accommodate findings in the data. The current study follows previous literature in the development of initial coding categories. These initial coding categories stemmed from the literature review of security and previous media discourse on terrorism. These are the "basic" categories described by Attride-Stirling (2001) as necessary starting points for thematic analysis. Understanding what kinds of evidence are able to count for this 
category requires living with the data for a period of time. One 'lives with' data by reading texts thoroughly multiple times.

Initial interaction with the articles involves taking notes and highlighting sections of text to consider contextual positioning. Security develops basic categories because there is not a codebook that can be written to clearly demarcate and isolate what does and does not as evidence for its presence. Security is ideological; it is not necessarily defined by the use of any particular words of phrases. This is why my process involves the application of many principles of Critical Discourse Analysis. Critical Discourse Analysis allows me to cull blocks of text from the newspaper article and position that text in relation to social developments. The idea is that a sentence never exists in a contextual vacuum; sentences and phrases are evocative, contextual, and dynamic. Encountering a block of text is also encountering the ideological package that the sentence is situated within and refers to.

After initial consideration and analysis of each article, I developed a codebook and turned toward thematic content analysis. A codebook in thematic analysis is not the same as one found in a quantitative study. I did not define criteria for the presence of a category and then assign numerical scores to the text in relation to those categories. Rather, my codebook is first built through understanding the ideological configuration of security. By understanding the configurations of security, I was able to process blocks of text through an ideological filter. When a paragraph or sentence represented the features of a category of security, it was placed under that category. This process obviously requires me to defend interpretations of the data as representing such a category, but that 
step is done in earnest later in the research process. Initial category application is about trying to make sense of the discourse on the page. Rather than extracting all portions of the text and evaluate the number of times a word or phrase repeats, this research process involves considering how each portion of the text is situated in ideological space.

The next part of the research process involves thematic analysis of the derived blocks of text. This is where the process flips from a deductive search for categories of security to analytically understanding how the discourse is positioned. I need to show how the text makes the presence of an ideology apparent, but I also need to let the text direct which themes are emergent. This process involved combing through the initial categories for words, phrases, and ideas featured across the newspaper texts. This process is open to subjective interpretation, which I guarded against by staying close to the text. My ability to argue for the presence of a particular theme is tied to using the words and phrases found in the text. As I present the findings for each theme, care will be shown for presenting representative quotes and blocks of text. My method utilizes the process of abduction. I moved back and forth between theory and the articles to see how things were ideologically constructed but with complete regard for the text itself.

Initial article sorting required grouping under the basic categories of: threat construction, stings and law, and dimensions of positive/negative peace. Basic categories are developed as the significant features of security. These are loose conceptual categories; they only serve to help organize the discourse at a very basic level. As the articles were coded under each category, I made notes about what types of patterns seemed to be emerging. I recorded the reasons it made sense to place a particular block 
of text under a particular conceptual category. This process guided the next step in the research process. As the articles were sorted into categories, it became clear that there are particular representations and patterns in the discourse. These do not map perfectly on the conceptual categories, but this is a good thing. My project is not concerned with testing a hypothesis about the presence of security discourse in the articles; it is concerned with understanding how newspaper discourse about F.B.I. sting operations is represented. The themes that emerge sometimes flowed in the opposite direction that security literature would have assumed. It was imperative that the data not be forced into categories that do not explain it in a larger social context. The text is always the reference point in this process.

As the articles were sorted in the larger conceptual categories, the notes taken about the different features of each quote were used to guide thematizing the content. I was concerned not just with how the articles fit within a category like threat construction, but the ways each block of text related with other blocks of text across the sample and across each larger conceptual category. For example, government officials are quoted with similar justifications for the use of stings in different articles. I developed a preemptive war theme to group instances of government officials discussing stings in a particular way and then re-evaluated each article to determine if it contained text that fit within this category.

Recall the initial process of thematic analysis: development of basic themes. My analysis suggests five dominant themes are present in newspaper discourse of F.B.I. sting operations. The themes are: Preemptive war; informants; targets; legal repositioning, and 
cooperative security framework. Each of these themes was then used to re-process each quote and block of text. Instead of trying to generally group the quotes along the categories of security, I was concerned with "saturating" the thematic categories made salient across the articles. Saturation occurs when a theme is developed and then all articles are resorted with consideration of that theme. Saturation is achieved through the iterative process. These themes emerged from close interrogation of the data and category reconfiguration/clarification throughout the data collection process.

The Toulmin model provides insight on both how I will present the findings from my research and perhaps provides greater clarification for the inductive/deductive approach utilized to get there. Attride-Stirling (2001) explains that the Toulmin model, "defines and elaborates the typical, formal elements of arguments as a means of exploring the connections between the explicit statements and the implicit meanings in people's discourse" (p. 387). The Toulmin model explains that an argument is formed through the scheme of claim-data-warrant. A claim is the overall argument being advanced. For this project, the claim is represented by the themes extracted from the data. I "claim" the presence of these themes. Data are the evidence one points to for justification of the claim. By presenting representative quotes, this study uses the language present in the articles for evidence. This allows readers to track the move from text to interpretation. In this study, the evidence is constituted by quotes culled from the articles. Finally, warrants are "principles and premises upon which the arguments in support of the claim are constructed" (p. 387). The warrants for this project are the analysis provided in the results section that connect the individual quotes/selections from the article to each of the 
identified themes. A similar configuration will be used in the discussion section, where I will argue for why each of the selected themes connects with, explains, and provides greater depth to the larger conceptual categories of security.

The goal of the results section is to present discourse in a way that explains the overall theme. By showing the narrative of the theme in the actual text of the articles, the current study is able to validate interpretations of the discourse. The text drives the interpretation at all times, so it is useful to see the ways newspapers present these ideas. Quotes are selected with concern for repetition and saliency. A quote is selected when its content repeats in other articles. Quotes are also selected for making a feature of the theme particularly clear or apparent. Finally, quotes have been selected across the sample. To avoid "cherry-picking" quotes, I made sure to include examples from as many different articles as possible. Rarely does an article have more than one quote represented here. My goal is to meaningfully represent discourse from the entire sample.

\section{Procedures: Sample Size, Saturation, and Limitations}

This study employs a sampling procedure that meets the demands established in the body of Critical Discourse Analysis literature. Creswell (2006) explains purposeful sampling strategies as selecting "sites for study because they can purposefully inform an understanding of the research problem and central phenomenon in the study" (p. 125). This gives researchers room to select artifacts for investigation with a guiding theory in

mind. Researchers from quantitative traditions may feel concern for this strategy because it risks bias. They might argue that selecting a sample with purpose would allow a researcher room to find what he or she were already looking for. My approach to this 
study attempts to bridge the gap between those concerns with the benefits of purposive sampling. Critical Discourse Analysis largely allows application of theory to the research process. My theory has been developed in many previous media studies of terrorism, so there is little risk in bias with its application.

Initial searches of "F.B.I. sting operations" and "War on Terrorism" returned 522 newspaper articles through the Lexis Nexis database. Drawing on previous research as a justification, this study limits the sample to the New York Times, Washington Post, and USA Today. After filtering other publications from my sample, 98 articles remained. I established a decision-rule for coding to eliminate articles that do not have content covering F.B.I. sting operations. Not all articles are structured as discussions of stings. For example, some articles discuss swings as a tactic used in an investigation, but focus significantly more attention on the crime itself. My sample includes articles that specifically mention stings in the context of the War on Terrorism. Some articles were removed because they analyzed a sting operation in the context of organized crime, which is too different of a theoretical construct from the War on Terrorism to justify inclusion. After filtering unnecessary articles, I was left with 75 for coding. These articles range in date from December 5, 1986 to April 12, 2015. This date range is necessary to understand the full context of sting operations. For example, by including articles prior to the terror attacks of September 11, 2001, I leave my analysis open to accounting for changes in the discourse over time. These articles were collected on April 12, 2015. A vast majority of the articles were published in the news section of the newspapers, however no articles were eliminated for appearing elsewhere [such as in the 
money section of newspaper, as was the case with a sting operation targeting individuals for financial crimes]. My sample does not include editorials, but only because no editorials appeared in the sample after the decision rules.

Lexis Nexis is a widely used tool for studying newspapers. However, there are several limitations associated with it. First, my search terms did not yield all articles related to newspaper coverage of F.B.I. sting operations. Kapoor et al. (2014) studied local newspaper representations of Mohammed Mohamud, an individual convicted through a F.B.I. sting operation. The articles I collected did not contain any of the articles presented in that study. Lexis Nexis is not robust in collecting articles from some regional newspapers. However, by focusing my analysis on the New York Times, The Washington Post, and USA Today, I have largely controlled for this problem. It is possible that different search terms would yield more or different articles from these newspapers, but I intentionally left the terms broad in order to capture as much of the data as possible.

I present an adequate sample for a few reasons. First, the newspapers selected for analysis represent the dominant news discourse of the US (Boykoff \& Boykoff, 2004; King, 1990). The benefit of including the New York Times and Washington Post is that such decisions have been made in previous research because of the credibility attached to each newspaper and the large social impact they have each have been measured to have (Boykoff \& Boykoff, 2004). Including USA Today in the sample represents a consideration of multiple forms of national news media discourse (King, 1990). 
While the Washington Post and New York Times are considered elite publications, the USA Today appeals to populous opinion and readership. Previous studies have evaluated all three newspapers together for these very reasons (Hawks \& Baruh, 2011). Hawks and Baruh (2011) note [of the New York Times, USA Today, and Washington Post], "those sources were chosen for discourse analysis as both being prestigious and mostly distributed newspapers in the US. Those newspapers present a broad view of anti-globalization coverage by the US mainstream media" (p. 136). One of the reasons it is useful to include three newspapers that have established reputation for representativeness of US news discourse is that it meets the burdens of Critical Discourse Analysis. Critical Discourse Analysis is best put to work when researchers analyze a complete body of discourse related to the research subject. By narrowing my research subject to the ways F.B.I. sting operations are discursively constructed in influential nationally distributed newspapers, this study can make a case for meeting that burden.

I employ category saturation through a blended grounded approach in this study. Category saturation is achieved by assigning all parts of a newspaper story to a relevant conceptual category. When subsequent evaluations of the newspaper collection reveal no further grouping of categories possible, saturation has been achieved. My approach is a blend of grounded theory because it begins with a theoretical guide instead of relying on such categories to solely emerge from the text. The reason for this is justified in the core Critical Discourse Analysis principle that states ideologies are sometimes opaque in their discursive form. One needs to know what to look for to find ideological constructions within text. This is especially true with security. Security authors contend the 
ideological foundations of security are deeply rooted in American consciousness (Campbell, 1992; Der Derian, 2002, 2008, 2009, Falk, 1991; Neocleous, 2008). As such, finding evidence of security requires careful contextual examination of text with the categories of security clearly demarcated.

Categories selected to guide this study are developed in the literature review. I looked for the ways newspaper discourse contributes to and is shaped by a framework of security. This will be accomplished by considering how the text establishes a need for security, justifies militaristic responses to threats, demonstrates the contingent nature of law, and securitizes peace. For example, if an article's discourse demonstrates need for F.B.I. sting operations because of the inevitable threat of terrorism, it can be taken as evidence for securitizing peace. The reason for this is simple: if the F.B.I. wishes to intervene in a person's life to prevent him or her from committing an act of violence, why would the F.B.I. not prioritize an intervention in line with positive peace? Instead of steering troubled youth to acts of violence, the F.B.I. could direct interventions in the form of reaching out to the individual with health care services or counseling. Given the massive scope of F.B.I. stings, one could conceive of thousands of alternative interventions than stings. The focus of this project is to draw out the discourse present in newspaper coverage and critically and contextually evaluate it within the framework of security.

This study is not solely a deductive approach. Data collection is a necessary prior step to theory application; however, an understanding and awareness of the politics of security is required to meaningfully collect data. Ehrlich and Romaniuk (2014) explain, 
“Given CDA's commitment to social critique, it is perhaps not surprising that most analyses begin with a social problem, as opposed to an interactional or discursive one" (p. 479). Security represents the social problem framing the current study. My goal in data collection is to be able to place the discourse within categories that can adequately explain the article contextually. This approach allows patterns to be made apparent and is evidence for reaching category saturation. This study also remains open to category reconfiguration if patterns in the text point are insufficiently explained with my theoretical guide. As such, it is a blended grounded approach. The text alone does not guide the investigation, but it serves as the complete basis for evidentiary support of my research questions. 
Chapter 4: Results

\section{Theme 1: Preemptive War}

There are two ways newspaper discourse is able to explain the field of War on Terrorism studies. First, newspapers tell us about the tactics used in the War on Terrorism. Second, newspapers can help explain the reasons these tactics are used and the thought-process behind them. A significant theme emerging from the data is the nature of F.B.I. sting operations as preemptive war. Thematic analysis of preemptive war accomplishes both goals of analyzing newspaper discourse; analysis shows the tactic (stings) and the thought-process explaining the tactic (preemption).

The quotes have been selected for representativeness of the sample and to reflect evidence in the form of sourcing. Each piece of discourse from the sample features quotes from top-level government officials. There are quotes from the President, the Attorney General, attorneys, and the head of Department of Homeland Security. These quotes are demonstrative of the discourse because they represent how newspapers cover issues like sting operations. Government officials are the only ones who can be quoted to explain and contextualize sting operations. Stings are enacted through government policy; F.B.I. policy is guided and shaped by government leaders. The discourse here represents a common theme identified by people who make policy.

Pre-emptive war fits within the context of the War on Terrorism. Because the War on Terrorism has no end-point, there is likely no conclusion to sting operations as a tactic. Threats of terrorism are permanent and thus the preemptive response to them must also be permanent. Preemptive engagement is characterized by searching for threats. 
Threats are not always situations where an attack is imminent; targets in sting operations are selected for being disposed to carry out attacks:

[stings are] "aimed at identifying and arresting people disposed to provide aid to terrorists” (2005, May 31). The New York Times, p. B1.

Rather than allowing the threat of terrorism to materialize in the form of money transfers or completion of a terrorist act, preemptive war strategies aim to curtail the risk of terrorism early. Several articles quote former Attorney General Eric Holder explaining F.B.I. stings:

"In the face of a threat so grave, we cannot afford to be passive," Mr. Holder said in prepared remarks. "Rather, we need the benefit of investigative and prosecutorial tools that allow us to be pre-emptive in our approach to confronting this problem" (2014, July 9). The New York Times, p. A9.

The language from this quote is telling. Holder says, 'we cannot afford to wait'. This shows the relevance of security literature in this theme. Preemption is necessary because of the risk of doing nothing. Notice how alternative forms of intervention are not presented. Because the risk is so great, the tactics must prioritize assertive action. The scope of which tactics are justified is great. Holder says we need to use all tools to preemptively fight terrorism; both legal and investigative policies should be used to their full degree. Sting operations are depicted as a necessary tactic because terrorism is necessarily a danger. 
Sting operations are specifically positioned as part of the government's campaign for pre-emptive intervention. Another article shows depicts language from thenPresident George W. Bush and Attorney General John Ashcroft:

"The fact that we were able to sting this guy is a pretty good example of what we're doing in order to protect the American people," Mr. Bush said at his Texas ranch. Mr. Ashcroft said the investigation "shows that all agencies of the federal government and our international allies will work together tirelessly to keep innocent people safe.” (2005, January 5). The New York Times, p. B5.

This excerpt demonstrates important features of the preemptive war theme. High-level government officials are aware of and willing to publically defend sting operations. President Bush uses language depicting the use of stings as part of the larger counterterrorism strategy. The language from Ashcroft shows that stings are a development where all aspects of government are directed to counter-terrorism. This indicates that while stings are certainly understood as preemptive action, they are not unique in the context of all counter-terrorism efforts. They are just one more incarnation of the desire to identity and securitize against the threat of terrorism. It is also worth noting the use of the word safety in this excerpt. Safety is recalled constantly as a way of positioning the shift to aggressive preemptive counter-terrorism policies.

The preemptive nature of stings is further explained as targeting more than an attack. Stings are also about identifying the intent to participate in terrorism. Another article excerpt explains: 
The government, since the Sept. 11 attacks, has been unabashed about using sting operations to catch people who prosecutors suspect may be inclined to aid or participate in terrorist plots. (2005, May 31). The New York Times, p. B1. This is an important aspect of the preemptive war theme, because it shows how threats are understood in the context of stings. Threats are more than imminent acts of violence; threats are configured as desires and intentions. Without an immediate ability or intent to engage in an act of terrorism, sting targets are selected because of what they believe.

Many articles explain the reasoning behind this kind of approach. The reasoning for preemptive war is always explained in relation to perceived threats of terrorism. The risk of allowing a terrorist attack to occur is so great that action must be taken to eliminate any potentiality for the threat to be realized. A quote from another article contextualizes this:

"The risk of waiting is just too great now," said Michael T. Shelby, the United States attorney in Houston. "Once we see that a threat is plausible, that it's real, and that a person has the intent to carry it out and takes some steps to show it's not just idle talk, that's enough for us to move." (2005, May 30). The New York Times, p. A10.

This excerpt shows that the government has to establish "intent" to justify targeting someone in a sting operation. Readers are left to consider how the government measures or quantifies something like intent. Consider a different situation put in these terms. Would the government be justified in arresting teenagers for the intent to drink alcohol underage? Teenagers sometimes wish to engage in such behavior, yet are limited 
because of access to alcohol and because of parental control. In similar ways, sting targets may have a desire or support for violence, but for a variety of reasons are exceptionally unlikely to be placed in situation where such actions are likely. Perhaps sting targets are also like other teenagers who would publically voice desire to drink alcohol, but may actually have no such desire or intent; they just talk a big game in the right setting.

The discourse displays a fear of waiting too long from the government. An article excerpt explains:

U.S. law enforcement officials say they do not have the luxury of waiting for a terrorist plot to mature before they break it up. A delay, they say, could mean that a member of the plot they had not discovered might be able to pull off an attack. (2006, September 2). The Washington Post, p. A01.

The excerpt demonstrates the logic of preemptive war; officials believe early action is the only way to prevent terrorism. The government argues that if they wait to intervene, they will not be able to stop the attack. As such, any possibility that someone may engage in violence requires action from the government. This excerpt also suggests that counterterrorism efforts not aimed towards preemption are a luxury. In this formulation, stings are not only justified, but they are the only proper response to the threat of terrorism.

One of the main champions of this move to preemption was former Attorney General John Ashcroft. A quote from an article captures the importance preemption played in constructing sting operations: 
Almost immediately after the attacks, Attorney General John D. Ashcroft announced "a new paradigm." Preventing terrorist acts, he said, was now more important than punishing crimes after the fact. (2011, September 11). The New York Times, p. F14.

The article goes on:

The new paradigm encouraged the arrests of people thought to be dangerous for, as Mr. Ashcroft put it, "spitting on the sidewalk," or for immigration offenses, or as material witnesses. It increased surveillance of religious and dissident groups. It ramped up the use of a law barring even benign support for organizations said to engage in terrorism, putting pressure on activities long thought to be protected by the First Amendment.

These excerpts show how sting operations reflect a paradigmatic shift in counterterrorism policy. Stings are not just one isolated tactic; they signal a significant reconfiguration of policy. The other important feature of these excerpts is the connection of stings with other aggressive tactics used in the War on Terrorism. Stings are justified through the same kind of logic that enables among other things, surveillance. The second excerpt captures the way a framework of security is emergent in discourse of F.B.I. stings. Security explains that states are likely to make all aspects of their policy contingent to preservation of safety against particular threats. In the Cold War this meant any time someone was identified by the government with even tangential support for Communism, it was justifiable to suspend their rights to enable prosecution (Campbell, 1992). Preemptive war points to a similar configuration in the War on Terrorism. 
The subsequent Attorney General, Alberto Gonzalez, is quoted in another article contextualizing the government's position on sting operations:

"Our philosophy is that we try to identify plots in the earliest stages possible, because we don't know what we don't know about a terrorism plot, and that once we have sufficient information to move forward with the prosecution, that's what we do," Attorney General Alberto R. Gonzales said at the Washington news conference. (2006, June 23). The Washington Post, p. A03.

The shift to preemption is expanded further by this quote. The government has a huge incentive to act as early as possible. The logic displayed here, "we don't know what we don't know" reflects the kind of paranoia that security authors identify. There is always a chance someone caught in a sting operation is an imminent danger, so the use of any tactic to remove such a threat is necessary. The need to act early assumes the need to use tactics that start as early as possible. What does early intervention mean? The discourse suggests support is tantamount to threat. So, the detection of a person's support for an extremist group is the necessary permission for targeting that person in a sting.

An important feature of this theme is what it represents in the context of other discourse related to the War on Terrorism. The War on Terrorism is frequently depicted as an ongoing battle between the US and non-Western countries. An important element of previous discourse deals with the Bush Doctrine, which was the stated US policy of preemptive missile strikes against nations deemed likely threats to US interests. A quote from another article demonstrates how the Bush Doctrine is now focused domestically:

"The old view that 'if we fight the terrorists abroad, we won't have to fight them 
here' is just that - the old view," Home-land Security Secretary Janet Napolitano told police and firefighters recently. (2010, December 20). The Washington Post, p. A01).

Sting operations are continually positioned as preemptive action against terrorism; they are discursively positioned in the context of shifting the War on Terrorism inward. The inward turn represents the core of the Bush Doctrine shifting away from framing outside threats of terrorism and moving to the interior space of the US. Preemptive war is a major thematic characteristic of F.B.I. sting operations in newspaper discourse.

Theme 2: Informants

The next major theme described through the data deals with role of informants in F.B.I. sting operations. Newspaper articles feature details on the ways in which F.B.I. stings are executed. A large number of articles include text about informants. An informant is someone hired or coerced by the F.B.I. to help facilitate a sting. Newspaper articles refer to informants with varying degrees of specificity. The reason for this is found in the nature of the subject covered by the article. Some articles detail particular sting operations while others discuss stings as a practice. When a particular sting operation is being discussed, the informants are frequently identified as having played a central role in the sting. An article demonstrates this feature:

The case underscores the murkiness that has been common to many of the government's terrorism-related prosecutions since the Sept. 11, 2001, attacks, cases that often hinge on ill-formed plots or debatable connections to terrorism. It 
is also the latest in a series of F.B.I.-run stings involving informants or government agents who pose as terrorists to build a case.

The indictment, which charges the men with seeking support from al-Qaeda to wage a "ground war" on the United States, is based primarily on Batiste's interactions with an unidentified government informant who posed as an al-Qaeda "representative" and discussed plans for bombings and assaults on the Sears Tower, the F.B.I. office in Miami and other targets. Batiste and the six others also allegedly swore an oath of loyalty to al-Qaeda during meetings with the informant, according to the charges. (2006, June 23). The Washington Post, p. A03.

This excerpt demonstrates how informants are described in many articles. Informants supply the F.B.I. with the most damning information about the sting target. This excerpt suggests that the lynchpin of a particular case was testimony from an informant concerning pledges of allegiance by sting targets. In this way, we can see the way informant testimony interact with security literature in the context of law. Entrapment defenses are difficult for sting targets to win because of informant testimony.

The informant question is clearly framed as playing a significant role in the sting operation in the first quote. This line of discourse is echoed in other articles:

Since the Sept. 11, 2001, attacks, separating serious terrorist plotters from delusional dreamers has proved one of the F.B.I.'s most challenging tasks. The effort is complicated by the bureau's frequent use of informants who sometimes 
play active roles in the plotting. (2006, September 2). The Washington Post, p. A01.

The above excerpt uses the language of active role to describe informant involvement in a sting operation. Readers are left to discern the extent to which the informant led the target to plan an act of violence. The excerpt also suggests that finding sting targets with actual predilection for violence is a challenge the F.B.I. has to overcome. This echoes some of the positive peace literature because it suggests the tactic for fighting terrorism is a search for the guilty. The project is not framed around promoting conditions that undermine the appeal of terrorism; instead the government prioritizes the militaristic response in the form of stings. Clearly these efforts sometimes target people who cannot be convinced to voice support for terrorism. However, it is still not clear that the targets eventually found guilty through these operations would have voiced support absent involvement from informants.

Discourse questioning the likelihood a sting target would have engaged in the activities they are prosecuted for repeats frequently:

"It's controlled from beginning to end by F.B.I.. But you can't create a terrorism case and then say you stopped it," Nubani said. "Had the F.B.I. not been involved, through their manipulation or informants, would the same thing have happened? Would there be attempted violence? They have their sights on certain people, the ones who talk big talk." (2012, February 18). The Washington Post, p. A01. This excerpt shows a few important details of this theme. The use of informants signals that the F.B.I. plays an active role in sting operations. Agents do not just track and record 
sting targets, they actively plan and dialog with them. The high-level of involvement is positioned as a reason to question whether the sting target would have acted illegally without government intervention. Another important feature this excerpt demonstrates is the kind of target selected for stings. It is not clear that targets are selected because they are most likely to engage in violence. The excerpt suggests sting targets are selected under the criteria of most vocal. Those who talk a big game are easier for informants to record saying incriminating statements. Positive peace literature would suggest the rationale or reasoning behind sting targets willingness for violence is most important; however, the discourse suggests such considerations do not matter at all. It is not a question of why, it is a question of what: What kind of support does the target have for extremist groups?

The characteristic of informants as leading targets to commit acts they would not have absent intervention from the government is echoed many times in the discourse. It usually appears in the form of statement released from Defense attorneys representing targets of stings:

He said Mr. Lakhani was incapable of performing any aspect of the missile transactions. He said an F.B.I. informer acted as a buyer and Russian law enforcement officials eventually stepped into the case and provided the one missile that was actually shipped to the United States. Mr. Klingeman said Mr. Lakhani had no predisposition to conduct the arms deal and thus was a victim of entrapment. (2005, January 5). The New York Times, p. B5. 
This excerpt shows the extent of informant involvement in sting operations. The sting target was charged with attempting to procure missile technology, however, the target had no experience or connections to enable such actions. The F.B.I. informant actually bought the missile and Russian law enforcement transported it. The role of the sting target is only support; a vocalized willingness. Without involvement from government agents, the target would never have been able to accomplish such an operation. This discourse reflects threat construction; the target is enabled to be a threat, they are not a threat on their own.

In another article the character of the informant is called into question as someone out-of-control:

The victory for the Justice Department came in one of the government's most visible terrorism-financing prosecutions, a case that had for a time appeared uncertain after the F.B.I.'s star informer set himself on fire outside the White House in November. (2005, March 11). The New York Times, p. B1. An important aspect of this theme is a questioning of informants. Not only are informants identified as having significant involvement in the sting, they are frequently depicted as individuals with questionable motives. In this excerpt, the informant is unstable enough to engage in self-immolation in front of the White House. Given the role informants play in overcoming "entrapment" defenses, it is concerning that these individuals are not selected for their competence or stability. If an informant is willing to engage in such extreme acts, perhaps the reliability of their testimony is also worth further consideration. 
The discourse shows competing narratives about the targeted nature of informant recruitment. Defense of informants comes in the form of commentary from F.B.I. representatives:

"We do not investigate people based solely on their race, ethnicity, national origin or religious affiliation," F.B.I. spokesman Paul Bresson said. "Our internal guidelines expressly prohibit this conduct as well as such tactics to recruit informants."

Court documents highlight major roles informants play in helping to identify what the government contends are potentially fatal plots. (2012, February 22). The USA Today, p. 2A.

The excerpt demonstrates a concern opponents of sting operations have levied in the past. Informants are recruited by the F.B.I. for stings. How informants are recruited is questioned in the discourse. This excerpt shows the F.B.I. defending against the claim that informants are coerced to serve in operations. The F.B.I. argues they do not profile communities for access to informants. It is suggested that internal policy prohibits such actions. However, this excerpt shows this is a point of tension between the F.B.I. and groups condemning their informant practices.

Another article excerpt clarifies the F.B.I.'s stance on beating entrapment defenses:

Dean Boyd, a spokesman for the Justice Department, said the affidavit in the Khalifi case makes clear that "at each step, it was the defendant who proposed the alleged plot and sought help in obtaining the weapons to carry it out." 
"Whenever we conduct an undercover operation of this sort, we fully anticipate that allegations of entrapment will be raised as a defense, and we conduct the investigation accordingly to assure that entrapment does not occur," he said. (2012, February 18). The Washington Post, p. A01.

The F.B.I. pushes back against the claim that informants play very active role in sting operations. They argue the sting target has to continually affirm desire to move the illegal activity forward. It is clarified that these are necessary steps to overcome an entrapment defense. This aspect of theme invokes the contingent law aspect of security. While the government is aware of entrapment as a concern with sting operations, stings are designed to avoid such an issue. This could mean that sting targets really do guide the entire operation, or it could also suggest that the F.B.I. has perfected the legal maneuvering of these operations. It is worth nothing that in any given sting operation, there is usually hundreds of hours of recorded information provided by informants. In hundreds of hours of recording, the sting target is depicted as voicing support. It is impossible for a judge or jury to listen to all of the recorded information, so readers are left to wonder about what information is omitted when these recordings are presented.

It is clear in the discourse that informants play an important role in executing sting operations. The articles suggest informants are sometimes recruited through financial means, while other times are pressured to be informants for pleading guilty to other offenses. The use of informants is frequently mentioned in the context of the F.B.I. taking on a greater role in counter-terrorism efforts post 9/11: 
Eleanor Hill, a former inspector general for the Pentagon who directed a Congressional inquiry into the Sept. 11 attacks, said the hijackings revealed severe shortcomings in the F.B.I.'s ability to develop informants and start undercover operations in terror cases, particularly after it was shown that some F.B.I. informants had had contacts with several hijackers.

"The F.B.I. has really been playing catch-up in a big way since 9/11," Ms. Hill said, "and we know now that the use of undercover agents and informants is absolutely critical to being able to infiltrate these groups." (2005, May 30). The New York Times, p. A10.

The quote above helps explain an important feature of the informant theme. The F.B.I. has shifted into an agency with the primary mission of counter-terrorism. Informants allow investigators access to first-hand testimony and significant control of the sting. Informants are frequently used to introduce the narrative of planned illegal activity. The F.B.I. is frequently quoted as saying that sting targets are selected because of the evidenced belief they will be likely to commit an act of terrorism with or without the push from informants. However, once targets have been selected for stings, there is varying discourse about how much involvement informants have in planning and suggesting acts of terrorism for the target. Most discourse signals informants are very influential in the process.

\section{Theme 3: Cooperative Security}

The theme of cooperative security perhaps best situates this project as analytic in nature. In attempting to code/group articles in relation to the category of positive peace, 
a surprising finding emerged from the data. A significant aspect of positive peace theory is undermined. Positive peace suggests that a securitized world leads major powers to inevitable conflict. Because every policy action is viewed as a zero-sum game between nations, there can never be sustained peace between them. Security literature also suggests that security coincides with the ways nation-states interact with each other. In this view, relations between major powers are unsustainable because competing global powers will be constructed as threats and securitized against. The data collected here points in the opposite direction. Rather than fostering a climate of distrust between major nations, sting operations seem to facilitate positive relationships:

The United States government estimates that there are more than 7,000 foreigners, including dozens of Americans, fighting in Syria. The Justice Department has offered to help other countries draft laws giving governments wider authority to prosecute people before they launch attacks. (2014, July 9). The New York Times, p. A9.

This quote demonstrates an important feature of the discourse. The US may increasingly focus counter-terrorism efforts domestically, but that does not foreclose attempts to resolve terrorism in other countries. The discourse points to efforts made by the US to help other countries adopt its security paradigm. These efforts link the governments to a common goal; detection and prevention of terrorism. This goal cuts through politics. Another quote demonstrates how even traditional enemies of the US can shift into cooperative partners under this paradigm: 
The case was, in effect, a complex double sting operation that unfolded over months. On one side the Russians, alerted by the American authorities, supplied the arms trader with the missile, which he tried to sell to American agents posing as terrorists. No real terrorists were ever connected to the plot. (2003, August 12). The New York Times, p. A1.

Sting operations sometimes require sustained interactions between countries. This excerpt suggests one such operation involved months of cooperation between U.S. and Russian operatives. Another feature demonstrated here shows that each country focuses on a particular part of the mission. The Russian agents supplied the weapons, while American agents facilitated buying the weapons. Specialization of a role in sting operations shows how a framework of security could lead to sustainable cooperation between countries. Each country brings unique benefits to sting operations, which means cooperation is strategic.

The discourse repeats with other nations, such as Egypt:

The defense is arguing that the case is trumped up, part of an effort by the United States Government to help the Egyptian Government by imprisoning Mr. Abdel Rahman. Defense lawyers say Mr. Salem was motivated by the prospect of the more than $\$ 1$ million that the F.B.I. has agreed to pay him for his work on the case. (1995, July 6). The New York Times, p. B5.

While this excerpt points to criticism about the nature of cooperation, it still demonstrates the U.S. and Egypt worked together to execute the operation. Moreover, the excerpt suggests the U.S. selects sting targets that other countries deem as threats. By 
prosecuting a sting target the Egyptian government views as hostile, the U.S. is able to both demonstrate its competence with counter-terrorism efforts and shore up relations with an important ally.

Allies to the US, such as Germany also benefit from the trading of information and intelligence that is required to execute complicated sting operations:

A statement from Attorney General John D. Ashcroft and F.B.I. Director Robert

S. Mueller III described today's arrests as "part of an ongoing terrorism-related investigation between the F.B.I. and German law enforcement," and they thanked the German government for its "excellent cooperation." (2003, January 11). The Washington Post, p. A18.

This excerpt demonstrates the ways sting operations facilitate positive relations between major world powers. As previously noted, security authors see the international system dominated by realism, which holds that nations view international influence as zero-sum. However, the excerpt reveals that counter-terrorism cooperation facilitates positive interactions between nations. Neither country gains influence over the other in trading information for sting operations; rather, both countries can argue they are safer from threats of terrorism. Officials use sting operations to publically solidify relationships with other nations.

Beyond fostering positive relationships between the US and other nations, stings also involve trading information between other nations. The framework of cooperation in terms of intelligence sharing gives countries the ability to craft counter-terrorism policies together: 
Just as Michelin has gone on selling tires in America, swaths of the FranceAmerican relationship have continued to run smoothly. The arrest of Christian Ganczarski -- a German Qaeda sympathizer arrested in June by the French police with alleged links to the bombing of a Tunisian synagogue in April 2002 as well as the Sept. 11 attacks -- was the result of an American-inspired sting operation with Saudi and French cooperation. "The cooperation with the C.I.A. and F.B.I. has become even stronger since Sept. 11 when the United States under-stood, as we did long before, the war against radical Islam," said Pierre de Bousquet, the head of the Directorate for Territorial Surveillance, France's counterintelligence service. "Nothing has changed because of Iraq." (2003, November 13). The New York Times, p. A14.

Discourse of cooperation is exemplified in several ways with this excerpt. Stings involve cooperation among agencies in the U.S., such as the F.B.I. and the C.I.A. Government agencies that may have historically competed for jurisdiction or prosecution now work together for a common purpose. The excerpt also shows how the logic of cooperation is formed; many countries have been victims of violence from extremist groups. Extremist groups operate through networks; they have cells in many different countries. As such, many countries have an incentive to prosecute high-level members of such networks. Sting operations allow countries to work together to execute the mission, because each country has a stake in the mission. 
The discourse does signal one way the relationships between nations in the counter-terrorism framework. The text indicates countries sometimes react negatively to sting operations from outside nations targeting their own citizens:

"The case has threatened to create an international rift because officials in Yemen, which has been increasingly helpful in fighting terrorism, say they are skeptical of the charges against Sheik Mouyad, the imam at a prominent mosque in the capital, Sana. He runs a large charity that provides food and clothing to the poor, works in the government ministry that oversees mosques and is active in the Isla political party." (2003, March 5). The New York Times, p. A1.

The discourse presented here represents an important theme in the data. Previous authors have narrowly defined the potential for cooperation in security paradigms. The assumption inherent to these works is that nation-states view other nations as their primary competition. This theme reveals a more complicated dynamic at play. Rather than forcing nations to securitize against one another, counter-terrorism in the form of sting operations, actually seem to facilitate cooperation.

There is a sense of cooperation found in the identification of a common-enemy. The enemy identified here is not one represented by a particular government; it is a network of groups that nation-states label/identify as terrorists. Nation states seem to view the presence of a threat aimed at allies as also a threat yet-to-be-realized for their own nation. While there are more implications of sting operations to work through, this discourse undermines an important aspect of positive peace/security literature. 


\section{Theme 4: Stings and the Law}

The next theme identifiable in the data also serves to undermine an aspect of previous security literature. Recall Agamben's conceptualization of the security state as being defined by the ability to suspend or remove law. The argument suggests that law is pushed aside in order to realize policies of security. However, the data point at a different configuration for how law operates in counter-terrorism. Law is not removed to facilitate sting operations; rather law is added and reconfigured. A prime example of this idea is found in discourse describing the government's use of the Sedition Acts to charge individuals with the intent to commit acts of terrorism. The following is an indicative example:

The key to the prosecution was a rarely used law -- the Sedition Act of 1918 -employed most recently against Puerto Rican nationalists and white supremacists. To prove a seditious conspiracy, the Government needs only to show that at least two people plotted to wage war against the United States and that each member of the group did so willingly. It does not need to prove that each member of the conspiracy knew about or took part in every act. (1995, October 2). The New York Times, p. B5.

The excerpt shows how old laws are used to prosecute sting targets. Just because an old law is rarely used, does not mean it cannot be invoked to secure prosecutions. This excerpt also shows that laws can be applied in new contexts. The Sedition Act has been used for counter-terrorism prosecution, but also for targeting white supremacist organizations. This suggests laws are utilized when they enable government prosecution. 
The government does not need to overturn laws to enable sting operations; they may invoke little-used laws in new contexts for such ends.

The government will use laws that have been inactive for decades to secure prosecutions. Another example is found here:

In many ways, the modern expansion of F.B.I. jurisdiction dates to the Omnibus Crime Control and Safe Streets Act of 1968 -- it was the law that gave rise to Freeh's UNIRAC case, among many others. Congress hoped it would help win the then-raging battle against organized-crime families. The law made wiretaps legal and bolstered the powers of federal grand juries. By the 1970s, it and similar laws had fostered the rise of large federal organized crime strike forces in New York and elsewhere. Along with innovative "sting" investigations such as ABSCAM, the famous 1980 political corruption case, and complex F.B.I. investigations of civil rights abuses in the South, these changes signaled new thinking about the scale and character of American federal policing. (1997, July 20). The Washington Post, p. W10.

The excerpt shows that federal agencies have been given wide-reaching authority for crime fighting. The OCSSA of 1968 was originally used to target organized crime, but has been utilized in different contexts since. The act directly enabled the utilization of various prosecution powers, such as expanding Grand Jury power and surveillance techniques. This excerpt suggests sting operations are a continuation of decades-long initiatives to expand federal power; it specifically invokes the language of new thinking. 
Another feature of the selected newspaper discourse is the reliance on new counter-terrorism laws to justify prosecutions in sting operations. This idea is represented by the following quote:

"Mueller said more than 200 suspected terrorists have been charged with crimes in the past 18 months; more than half have been convicted and the rest are awaiting trial. In the one-year period that ended Sept. 19, he said, the F.B.I. obtained 113 emergency secret warrants to keep tabs on foreign nationals under the Foreign Intelligence Surveillance Act. The agency obtained 46 such warrants in the previous 23 years." (2003, March 5). The Washington Post, p. A09.

This excerpt positions sting operations as part of many new efforts prioritizing counterterrorism. The legal sphere enables counter-terrorism policies through legislation like the Foreign Intelligence Surveillance Act. The F.I.S.A. permits government operatives to use "emergency secret warrants" for targeting terror suspects. It also makes clear that the government dramatically increased the number of attempted prosecutions for terrorism after September 11. The discourse presented here shows that there is no appeal or response to sting operation on the basis of legality. The legal system enables policies of security, exemplified by sting operations.

The preceding excerpt invokes F.I.S.A. as a way the government navigates the legality of stings. Another article shows how the Patriot Act is used in similar ways: A number of other undercover operations are continuing, officials said, and the Justice Department has committed more prosecutors and investigators to handle informants in terror cases and to initiate undercover operations. The recent 
prosecutions also reflect, in part, the Justice Department's improved ability to develop better communications in secret investigations as a result of structural changes put in place under the antiterrorism law known as the USA Patriot Act, officials said. (2005, May 30). The New York Times, p. A10.

The excerpt shows that sting operations have received special attention from the legal sphere. The Justice Department appoints prosecutors to handle informants and is given permission to conduct secret investigations. The Patriot Act is invoked to justify legal expansions for sting operations. The theme demonstrates the dynamic maneuverability of the legal sphere in relation to terrorism issues. The Patriot Act is specifically designed to navigate legal impediments to counter-terrorism; it is not surprising to see it used for sting operations, which are continually situated in the context of dramatic counter-terror expansion in the post September 11 world.

The data also point to the legal status of stings as being decided in other contexts. For example, instead of seeking court approval for a particular tactic in a sting operation, the F.B.I. uses legal justifications established for NSA surveillance. The following quote demonstrates this feature:

Aside from the director, F.B.I. officials did not question the legal status of the tips, assuming that N.S.A. lawyers had approved. They were more concerned about the quality and quantity of the material, which produced "mountains of paperwork" often more like raw data than conventional investigative leads. (2006, January 17). The New York Times, p. A1. 
This excerpt is interesting because it points to the legitimacy of this theme applying to other aspects of the War on Terrorism. Sting operations are enabled through legal protections given to the National Security Agency. Rather than seeking its own legal approval, the F.B.I. assumes the legality of their actions are covered by other agencies. The last line of the quote is also telling. The F.B.I. is much less concerned with the legal questions surrounding counter-terrorism intelligence than they are with the quality of the evidence gathered. Thus, while laws are not removed to facilitate stings, they are certainly positioned as contingent on security claims.

Another important feature of stings the data reveal is knowledge of the legal grey area surrounding sting operations. The F.B.I. acknowledges the potential for legal challenges to their cases. This is obvious because the end-goal of a sting operation is securing a conviction of the target. This logic is present throughout the discourse and is represented here:

"Whenever we conduct an undercover operation of this sort, we fully anticipate that allegations of entrapment will be raised as a defense, and we conduct the investigation accordingly to assure that entrapment does not occur," he said. (2012, February 18). The Washington Post, p. A01.

This suggests that perhaps the legal definition of entrapment may be different than many quoted in the articles assume it to be. Defense attorneys have attempted and lost with an entrapment defense in several sting operations. The F.B.I. clearly understands the nature of the legality surrounding entrapment and designs the operation to avoid such concerns. 
Readers of this discourse may wonder what counts as entrapment if sting operations do not, but those questions are not present in this locus of articles.

The F.B.I. is given explicit approval to operate sting operations by Federal judges: Marc Raimondi, a Justice Department spokesman, said: "The Department of Justice has been a steadfast ally of our nation's civil rights groups for decades. The report itself acknowledges that the legal process used in the cases it highlighted is not only lawful but is also specifically approved by federal judges. . . We do not and cannot target individuals solely for engaging in activities protected by the First Amendment, which includes free speech and religion." (2014, July 22). The Washington Post, p. A07.

It is interesting to see this excerpt in consideration of excerpts displayed in the preemptive war theme. Several excerpts demonstrate how government officials believe support for extremism is reason enough to target individuals in sting operations. This excerpt suggests such tactics are not used in sting operations. However, the context for this excerpt is to address legal challenges to sting operations. Thus, while stings probably do target individuals for voicing belief and support, they fail to cross a legal threshold for doing so that would make using them illegal.

The data help explain how tactics in stings that are not covered under current law are made permissible. Government officials seek to create new laws expanding their power to execute sting operations. One such example is found in this quote:

Holder urged other countries to pass legislation that criminalizes "preparatory acts," laws such as the material-support statute in the United States that allows 
law enforcement to arrest and prosecute individuals in the initial planning stages of terrorist plots. France and Norway enacted similar statutes in the past two years, and Norway, whose intelligence agency estimates that 40 to 50 of its citizens have traveled to Syria, charged the first person under its law in February. (2014, July 9). The Washington Post, p. A07.

The features of the data contained in this theme explain the way stings are constructed in a legal framework. Stings are not represented as an end-around law. The F.B.I. is highly aware of the intersection of law and counter-terrorism. The discourse speaks to law being made contingent to F.B.I. counter-terrorism policies. When the F.B.I. isolates sting operations as an important tactic in fighting terrorism, law is either re-applied in new contexts, new laws are passed, or legal interpretations for similar tactics in other contexts are appropriated. In this way, stings are not discursively represented as a curtailment of law. They are positioned as entirely legal.

\section{Theme 5: Ordinary Targets and Dramatic Attacks}

The fifth theme demonstrates overt connections to security literature. Targets in

F.B.I. sting operations are not people who have immediate access to explosives or connections with extremist groups. In the classic sting configuration, government operatives attempted to get inside information about mafia groups because of the difficulty getting people to talk about their illegal activities. The mafia assassinated people who went to police, which had a chilling effect on people's willingness to participate in investigations (Aaronson, 2013). Stings allowed government operatives to 
get first-hand accounts of organized crime activity, but with the ability to get such information into trials.

Stings in the War on Terrorism work much differently. The government is not setting up stings because it is trying to infiltrate established crime networks; they use them to intervene against individual people who express support for extremist groups (Aaronson, 2013). The second ways this theme aligns with security literature is dramatic nature of the attacks planned. Sting targets are led to plan violence such as blowing up the Sears Tower and detonating a bomb in downtown Portland. If the goal is to remove inevitable threats of violence from the street, why does the government need to help targets plan such dramatic attacks? Security literature suggests that the threat scale is magnified by the nature of the attacks. In the law theme, it was obvious that the scale of threat determined the extent to which laws would enable government intervention. The total effect of these discursive formulations is that threats are real, threats can come from anywhere, and thus, aggressive preemptive responses are necessary.

Newspaper discourse of F.B.I. sting operations in the War on Terrorism represents the targets of sting operations in particular ways. Targets are the people accused of attempting to commit acts of terrorism. The F.B.I. is represented as selecting targets neutrally; showing only concern for targets they say will inevitably commit acts of terrorism:

"What this comes down to is you have some guys -- they're not charged because they were planning a bombing in this country, and they're not charged because they were planning a bombing in another country," said one senior law 
enforcement official who has been briefed on the investigation. "But they are jihadi sympathizers who at the very least were looking forward to getting some people trained here and getting them shipped out to Afghanistan so they can join the war." (2005, May 31). The New York Times, p. B1.

Notice the way the sting target is portrayed here. The target is not portrayed as planning an imminent attack or being likely to connect with an extremist group. The law enforcement official quoted in this excerpt suggests the target is selected for looking forward to help with training. They have not done any training; they just might have an internal desire to do so. Sympathy for Jihad is tantamount to terrorism in this configuration. The discourse signals that targets of stings are not high-level operatives in extremist groups; they are people with sympathy for those causes.

This discourse repeats throughout the data. Another example shows "the likelihood to commit acts of terrorism" as the primary driver for target selection:

“You can't put a percentage on how likely these guys would have been to commit an act of terrorism," Mr. Pericak said in an interview in his office at the federal courthouse here. "But if a terrorist came to Albany, my opinion is that these guys would have assisted 100 percent." (2007, August 8). The New York Times, p. A1. This excerpt shows the problematic configuration of risk at play in F.B.I. sting operations. The government decides who to target with stings on the basis of his or her likelihood to engage in acts of terrorism. However, there are no criteria for making such determinations identified in the discourse. The official quoted in this excerpt actually suggests that it is impossible to quantify such a risk. This does not prevent government 
operatives from utilizing stings, it just shifts the burden of guilt proof in the opposite direction. If a person is identified by an informant or agent as having support for extremist causes, sufficient grounds for a sting are established. Risk assessment plays out in a paranoid way; this excerpt suggests if a terrorist for some reason targeted Albany, then the individual arrested in a sting would most certainly have joined him or her. The official does not attempt to quantify this logic because it is not seen as necessary.

A competing discourse is represented through Defense Attorneys of those targeted in sting operations. The discourse suggests that some people do not believe the likelihood construct used by the government. Several quotes demonstrate disagreement concerning the likelihood of targets committing acts of terrorism, absent government intervention:

But Mr. Lakhani's lawyer offered a sharply different image during his opening arguments. The lawyer, Henry E. Klingeman, depicted his client, a 69-year-old Briton born in India, as an innocent clothing merchant who had no sympathy for terrorists or Muslim fundamentalists, was incapable of smuggling missiles or any other weapons into the United States, and had been entrapped in this case by law enforcement officials from the United States, Russia and Britain. The only figure in the trial who is not a government agent or law enforcement official is Mr. Lakhani, Mr. Klinge-man told the jury. "Ask yourself," he said, "would any of this have occurred without the government?" He described Mr. Lakhani as a middleman "surrounded on all sides" by government agents. "Like a Hollywood 
movie, this case is a work of fiction." (2005, January 5). The New York Times, p. B5.

While it would be misguided to suggest someone's career makes her or him more or less likely to commit acts of violence, the discourse nonetheless mentions such things frequently. The sting target in this example is a clothing merchant. There is no mention of the target having connections to extremist groups or abilities to procure offense weaponry. The excerpt suggests that the target was completely surrounded by government agents, which makes it difficult to know the degree of likelihood that this person would have engaged in acts of violence absent government intervention.

Civil rights advocates are also quoted showing objections to stings. Organizations question how likely sting targets are to act absent F.B.I. intervention:

"The report clearly shows, in many respects, the American public is being sold a false bill of goods," said Andrea Prasow, deputy Washington director at Human Rights Watch. "To be sure, the threat of terrorism is real," she said. "But in many of the cases we documented, there was no threat until the F.B.I. showed up and helped turn people into terrorists." (2014, July 22). The Washington Post, p. A07. The language used here is dramatic; a Human Rights Watch official argues the government helps turn people into terrorists. This not only suggests sting targets are unlikely to commit acts of violence, they are actually directed to more extremists views than they possessed prior to the investigation. Civil rights groups are infrequently quoted in the articles, but when they are, it is always with logic like the excerpt above displays. 
At times the discourse provides details about the target. These descriptions represent targets as average people who voice radical views. An average person is certainly capable of doing terrible things. However, the likelihood of an average person possessing the means or willingness to commit an act of terrorism is held in question throughout the discourse. One such example appears here:

"The problem with all these cases the government has brought is that none of the people apprehended are people with a history of dealing in weapons, much less weapons to terrorists," he said. "These are people who express a willingness to do so, but either they have not done so, or they couldn't even if they wanted to. In my view, all the man-hours and money the F.B.I. is devoting would be better spent on real threats." (2005, May 30). The New York Times, p. A10.

The excerpt clearly positions this theme in the context of security. People selected as targets in sting operations are led to plan and discuss violence that they have no previous experience with. Stings do not just lead people to use their particular skills to commit acts of terrorism; government agents lead people with ordinary skills to attempt things completely outside of their every day experience. This excerpt delineates threat in sting operations from real threats, and thus positions the discourse in a security perspective. There are a few explicit mentions of targets being in employment positions one would likely never associate with providing opportunities for extremism. One such quote describes a sting target that is also a pizza parlor owner:

In Albany, relatives, friends and acquaintances of both men insisted they were innocent. Mr. Hossain, a native of Bangladesh who owns a popular pizza parlor in 
downtown Albany, is one of the founders of the Masjid as-Salam Mosque in Albany, and he recruited Mr. Aref, a Kurd from Iraq, to be the imam of the mosque, officials said. (2004, August 6). The New York Times, p. B1.

A similar piece of discourse identifies a doctor and martial arts expert/jazz musician as targets in a sting operation:

Mr. Shah, a jazz musician, and Dr. Sabir, a physician, have not entered pleas in the case. The two men, lifelong friends, stand accused of trying to provide support to Al Qaeda, and vowing to use their knowledge in martial arts and medicine to help international terrorism. After the arraignment, Anthony Ricco, one of Mr. Shah's two lawyers, said the arrest was typical of the government's efforts to cast suspicion on Muslims in the aftermath of the Sept. 11 attacks. (2005, June 1). The New York Times, p. B3.

Readers are left to wonder how teaching terrorists martial arts represents a significant threat to security. It is also worth noting that providing medical treatment is also tantamount to terrorism in sting operations.

While the targets specifically identified in the sample are depicted as having ordinary jobs, the acts of terrorism they are arrested for facilitating are anything but. Two important features related to the act of terrorism targets are arrested for attempting emerge from the data. The first feature is developed in the informants theme. F.B.I. operatives are influential in determining the nature of the terrorist attack the target is setup to commit. Through informants or F.B.I. agents, targets are led to talk about and plan operations with ideas supplied to them. The other important feature of these acts of 
terrorism is the dramatic nature of the planned attacks. Rarely are targets arrested for attempting to train Al Qaeda in martial arts; frequently, targets are arrested for attempting acts of mass destruction. One such example presented here identifies a sting target wishing to blow up the Sears Tower:

Federal authorities announced charges here Friday against seven men they described as "a homegrown terrorist cell" that planned to blow up Chicago's Sears Tower and other buildings. But officials conceded that the group never had contact with al-Qaeda or other terrorist groups and had not acquired any explosives. (2006, June 23). The Washington Post, p. A03.

The planned attack identified here is dramatic; it involves the imagery of September 11 in the sense that the targets wanted to level a skyscraper with particular cultural relevance. The excerpt implicitly suggests that this plan was half-baked because the targets never acquired any material that would enable such an attack.

Another operation identifies a target wishing to detonate a bomb during a holiday ceremony in downtown Portland, Oregon:

The bomb, which was in a van parked off Pioneer Courthouse Square, was a fake -- planted by F.B.I. agents as part of the elaborate sting -- but "the threat was very real," Arthur Balizan, the F.B.I.'s special agent in charge in Oregon, said in a statement released by the Department of Justice. An estimated 10,000 people were at the ceremony on Friday night, the Portland police said. (2010, November 28). The New York Times, p. A1.

Other times, targets are depicted as planning attacks on the capitol: 
The man, known as "Yusuf," was actually an undercover F.B.I. agent, one of two key players in an elaborate sting operation that would result in El Khalifi's arrest last Friday on charges that he plotted to detonate a suicide bomb inside the U.S. Capitol. (2012, February 22). The USA Today, p. 2A.

Both excerpts demonstrate the scope of this theme. Sting targets are led to plan terrible acts of violence: acts of violence that would inevitably produce thousands of casualties. If the government has complete control of the operation, why is it necessary to plan such dramatic attacks? Would money-laundering convictions not equally remove the threat posed by sting targets? That these alternative configurations are never suggested in the discourse is evidence of security as an organizing principle.

This theme encapsulates two important features of the discourse covering F.B.I. sting operations in newspapers. Targets selected for F.B.I. sting operations are people who do not have ties to extremist groups. Targets are identified as every day people, with ambitions for committing acts of violence. These findings are also reflected in the work of Kapoor et al. (2014). The authors analyze local media representations of one sting operation in Portland, Oregon and found these characterizations repeated often in the data. The discourse establishes competing narratives concerning the nature of sting targets. When government operatives speak about targets, the language typically identifies them as inevitably carry out terrorist attacks. F.B.I. discourse suggests that only through government intervention is the attack rendered incapable of harming others. Civil rights advocates and defense lawyers represent the other side of the narrative. They suggest targets may talk a big game, but have no ability or intention to carry out terrorist 
attacks. The discourse represents the nature of this competing narrative and contextualizes why it matters in the form of the planned attacks. 


\section{Chapter 5: Conclusion}

\section{Discussion}

\section{Answering Research Question 1: Prevailing Themes}

Research question one asked: What are the prevailing themes present in newspaper coverage of F.B.I. sting operations? The answers to this question are identified in the results section. The prevailing themes of F.B.I. sting operations in newspaper coverage from The New York Times, The Washington Post, and USA Today are: Preemptive war; Informants; Cooperative Security; Stings and the Law; and Ordinary Targets, Dramatic Attacks.

While each theme is presented as unique and contains its own evidentiary support, it is useful to consider the relationships between them. It seems apparent that the preemptive war theme serves to explain the discourse collected under the other themes. Preemptive war is described in specific language by a range of government officials: the President, the Attorney General, the head of the Department of Homeland Security, and F.B.I. representatives. The people in charge of crafting and executing counter-terrorism policy are the ones explaining the logic of preemptive intervention. The rest of the themes contextualize how preemption is executed in sting operations.

Preemptive war requires the use of informants and dynamic applications of law. The data are a description of informants being used to initiate contact with sting targets and to varying degrees aiding those targets in planning acts of terrorism. Analyzing the data shows this process negotiated between two legal narratives. One side argues that laws can be applied in new contexts or new laws can be generated in order to protect 
against terrorism. The other side argues that sting operations target vulnerable populations by entrapping them to commit crimes they never would have without intervention from the government. However, one side has more influence than the other in this equation; the government decides whether to use stings as a tactic. Government officials describe stings as an important development in domestic counter-terrorism efforts. The data suggest there is no movement to decrease the use of stings; rather, the tactic is successful at apprehending people the government identifies as dangerous and will continue to be utilized for that reason. As a result, analyzing informants and the role of law demonstrates features of a sting.

The law, as represented in these data, does not hold power to constrain the scope of stings. Legal norms are described as contingent to security. The discourse points to arguments concerning the devastating implications of acts of terrorism as the primary reason. Laws should not limit the state's ability to protect its citizens. This configuration allows us to see what ideology actually means in the sting framework. Safety is a primary ideological configuration. Safety concerns guide Federal judges to create special permission for a variety of practices centered in sting operations.

Informants represent a specific way that legal norms are placed secondary to questions of safety. While it remains illegal for the government to entrap individuals, the meaning of the word entrapment needs to be considered with greater detail. What does it mean to entrap someone? The F.B.I. suggests stings do not constitute entrapment because the target is dangerous and predisposed to commit an act of terrorism. Opponents of stings argue that entrapment occurs in stings because the selected targets 
would never have actually committed the acts they are charged with. Informants are the necessary explanatory piece of this puzzle. Informants are able to record and collect evidence about the nature of targets in stings. Because informants are able to draw out specific language about intent from sting targets, the state is able to beat the entrapment defense. We are left to wonder why the government does not track and monitor people they believe will commit act of terrorism; why do they need to arrest them through a sting operation? Would it not be possible to intervene at the time when a target actually attempts to commit an illegal act? The framework of preemptive war answers such questions: Why risk it?

It makes sense for nation-states to work cooperatively in counter-terrorism efforts. Terrorism is not a state-centric issue in the sense that it does not have a particular point of origin and does not target a particular state. Acts of terrorism can occur in and against any particular state. All states share the potentiality for being targeted by terrorism. The framework of preemptive war unites states in counter-terrorism efforts. The U.S. is guided by its own security concerns to spread its counter-terrorism efforts around the world.

Preemptive war isolates would-be terrorists before they can commit acts of violence. In this framework, the potential for a pizza parlor owner or a martial arts expert to engage in violence justifies targeting those people in sting operations. The spectacular nature of the acts of violence isolated in the data justifies these actions. Maybe a pizza parlor owner would be unlikely to meet up with Al Qaeda operatives; but the chance he or she could means shocking violence could be realized. The probability of such 
concerns is backgrounded to the magnitude an act of terrorism represents. Preemptive war sees the potential for violence as sufficient grounds for intervention.

\section{Answering Research Question 2: Connecting Themes to Security}

Research question two asked: In the context of national news coverage of F.B.I. sting operations and the War on Terror, what are the prevailing themes concerning security? Consideration of each major category of security reveals strong connections to themes developed in this project. The categories of security developed in this study are: threat construction; militaristic responses to threats; security and exception; and securitizing peace.

Threat construction is defined by an ideological recognition of threats. Threats are not objective conditions: threats become political when they are recognized by the state. An Ideological State Apparatus is likely to hail threats representing challenges to its control (Althusser, 1971). Terrorism is in service of challenging the ideological hegemony of the West. This is not to say terrorism is defensible, only that it happens for reasons. In sting operations, threats are constructed in the form of support for terrorism. The discourse suggests sting targets are not likely to engage in terrorism absent government intervention. As a result, the condition of their danger is constructed. It is constructed on the assumption that support is tantamount to risk, because support might lead to action if the target were to encounter an extremist group in his or her community. As represented in the discourse, F.B.I. sting operations reflect the features of threat construction. 
The militaristic response to threats is present in the discourse. The government does not intervene against targets in the form of social support; they do not offer counseling services to troubled young people drifting to support of extremism. The response to potential threats is to utilize the full scope of policing power. Stings incorporate aggressive prosecutions, surveillance, and informants to secure prosecutions. Prosecution is a militaristic response because the goal is to imprison dangerous bodies; not to help understand the situation or lead the target to a different path.

The cooperative security theme resituates previous discourse in the War on Terrorism. Hodges (2011) identifies a tendency for discourse in the War on Terrorism to construct an us v. them dichotomy. The U.S. is portrayed as a champion of democracy and freedom. Other nations are either a part of coalitions led by the U.S. or are depicted as in opposition to the virtues enabling freedom to be spread throughout the world. There is a tendency for U.S. officials to portray other nations as either strong allies or ideological enemies (Hodges, 2011). Newspaper discourse of F.B.I. sting operations changes the dimensions of the us v. them. Rather than other nations being portrayed as impediments to the War on Terrorism, they are shown as cooperative allies. Even countries like Russia and Syria are depicted as trading information and building joint policy with the U.S. Countries are depicted as uniting around creation of a new enemy; terrorists. So, while us v. them is still powerful in explaining the discourse; the us has changed to nation-states, and them has changed to terrorist others.

As mentioned above, the data does not support some of the conclusions surrounding security and exception. Rather than removing laws or declaring states of 
emergency, the legal system actively enables counter-terrorism policies like sting operations. Federal judges issue special permissions and new laws are crafted to achieve security. This can be taken for evidence that a more nuanced understanding of exception is required. Perhaps in modern counter-terrorism policies, exception is defined not by the ability to suspend laws, but by the ability to make legal norms contingent on security. When security rhetoric, such as the threat of terrorism, is invoked, agencies are given nearly unlimited legal latitude to respond to those threats.

Finally, sting operations are well situated in the securitizing peace category. When the government has enough actionable intelligence to identify a person as a safety concern, stings are the outcome. Security literature explains that the only intervention we can expect is the kind represented by stings. The government does not try to divert sting targets to other activities or attempt to dialog with them in order to understand why violence seems like a proper response to government policy. Informants investigate targets and attempt to record them dedicating themselves to acts of violence. Sting operations do not ask about the root cause of the problem they seek to resolve. In fact, the discourse shows that stings sow distrust in Muslim communities. By using informants, the F.B.I. creates the perception that they have infiltrated communities; they are not allies so much as occupiers. This framework reflects negative peace. The government is dynamic in responding to threats, but lacks the ideological configuration required to resolve them. Resolving threats of terrorism requires reconfiguring the security state; sting operations deepen it. 
Newspaper discourse tells us about the features of sting operations and the ideology embedded in the practice. Security is grounded through this thematic analysis; we can pinpoint what security means in an empirical way. Sting operations are represented discursively as a major feature of the War on Terrorism and are couched in the language of preemption. Preemption cuts across the categories of security developed in the literature review. To preempt threats, a state must process what counts as a threat and decide action based on the nature of the threat. Stings demonstrate which threats are most important to the U.S. government: threats of terrorism. Stings also echo threat construction in the way targets are selected. Targets are selected for stings on the basis of intent to commit violence; not necessarily on the basis of which threats are most probable.

The data also show the need to update understandings of security. No longer is security aimed at other nation-states, it is aimed at non-state actors (Kapoor et al., 2014). This allows cooperative bonds between nations to be formed because a common enemy exists. Security also assumes a removal of law as a primary tactics. Modern legal discourse does not seem to work that way. Laws are updated, changed, resurrected, and created to facilitate security; they are not pushed to the side. Allowing law to be contingent on the security paradigm shows us ideology, because it questions any inherent quality to law other than preservation of safety. The government can advocate for changes in law on the basis that doing so will better facilitate state actions to keep people safe from terrorism. This is ideological because it shows us that the real framework for law, government intervention, and tactics in the War on Terrorism, is security. Security 
trumps all other issues and therefore is the guiding ideological framework. Stings allow us to see security in practice.

\section{Answering Research Question 3: Subjugated Discourse}

Research question three asked: How does newspaper discourse of F.B.I. sting operations omit alternative interpretations or discursive constructions? The most important question left unasked by the discourse in the newspaper article concerns alternative interventions. It is important to consider the nature of the sting. Rather than setting targets up to engage in smaller acts of illegal activity, like money laundering or something similar, people are led to pledge commitment for blowing up major buildings. The discourse is clear on this question. Readers are left wondering: why not a different form of government intervention? Why not remove dangerous people from the streets under offenses that do not send them to prison for decades? The framework of security directs governments to militaristic responses to terrorism. It does not lead governments to ask about the root cause of the situation. As such, even though stings conceivably remove would-be terrorists from society, they can never hope to eliminate the threat of terrorism because they establish conditions of alienation enabling recruitment to extremist groups and support for violent causes.

Should we expect newspapers to cover these kinds of issues? Perhaps not. Newspapers rarely have the stated goal of reconfiguring government policy; they are in service of informing the public about policy. Newspapers can only tell us the reasons the government publically defends for using stings to fight terrorism. In covering sting operations, newspaper do not ask questions about alternative forms of intervention 
because the government is not asking those kinds of questions. There is no one to quote to advance such a position. As a result, the newspaper discourse subjugates alternative configurations to resolving terrorism.

\section{Limitations}

It is worth noting a few important limitations to this project. First, not all discourse on sting operations is present here. Sting discourse exists in regional news publications, television reports, legal journals, and a variety of other places. This project cannot claim to represent the totality of the discourse related to stings. The nature of newspaper readership also is a limitation. People do not necessarily read every newspaper article for a subject area. They probably encounter a story in one newspaper. Although I have a representative sample of newspaper discourse, people do not encounter newspaper discourse across publications and time. While themes emerge across newspaper discourse, the power of even one article is amplified, because people may only ever read one newspaper article about a story. Thus, even if a claim can be made that the discourse is "securitized", this does not mean it is possible to map such implications on society. This project does not attempt to do so. It is about drawing out the discourse and contextualizing it in a theoretical way.

\section{Conclusion}

\section{Discursive Security}

This paper makes the case for security in discourse. Discourse reflects and builds a framework of security. In the case of sting operations this plays out in two important ways. First, sting operations serve to securitize the public against the threat of terrorism. 
Securitization utilizes the fear of danger to maintain public support for state power (Dillon, 2008). Sting operations lead targets to plan operations that would certainly establish a fear of danger. How else could the public respond to a 17-year old attempting to detonate a weapon of mass destruction in downtown Portland? Security authors suggest there is a reason why such dramatic attacks are planned; the more dramatic the nature of the attack is, the easier it is to defend the operation that led to its planning. People tend to not ask about the legitimacy of sting operations, when the government can make the case that they prevented the deaths of tens of thousands of people. The weight of the threat sinks opposition to the tactic utilized to prevent it.

Security is discursive. No one can point to an object and say, "this is security". It has to be argued for as an ideological construct. Security describes a host of safety practices with concern for their meaning. This argument is affirmed by this project. Without security, newspaper articles concerning F.B.I. sting practices are only descriptions of policy. With security, the discourse presented about F.B.I. sting operations can be explained and contextualized in a larger social context.

The final step of Critical Discourse Analysis is to suggest or point to potential changes in the social world. The data presented here show many ways security is embedded within discourse pertaining to F.B.I. sting operations in the War on Terrorism. If many authors are correct in arguing that security structures the world in ways that perpetuate violence and death, then moves away from the security framework are necessary. There are two ways this project suggests security can be addressed. First, newspapers could account for subjugated discourse relating to alternative ideological 
approaches to threats such as terrorism. If newspapers are politically important, this function would serve to productively reorient citizens to their society. Second, the F.B.I. and other government agencies could end sting practices and other such policies oriented around a scheme of security. The government could prioritize social welfare and attempt to build policies of engagement rather than prosecution. Both of these solutions would do much to deconstruct the dominant framework of this time: security.

\section{Closing Remarks}

This project began as an exercise in understanding terrorism discourse. The literature identifies such discourse as securitized. The War on Terrorism is defined by the tendency to construct threats, respond to them with military interventions, and build policies that preemptively act to prevent threats from being realized. Sting operations are an important tactic in the War on Terrorism and thus are connected with the security paradigm. This project maps the modern trajectory of security by accounting for a major feature of the War on Terrorism. Positive peace literature suggests the current configuration of security leaves us in a world where the War on Terrorism will never end. The desire to securitize against threats leads to tactics that sow deep mistrust between certain populations and the state. This distrust is the space where radicalism grows and proliferates. In the end, this paper makes a case for security as discursive contruct. Security is found in newspaper text defining, explaining, and contextualizing F.B.I. sting operations.

Studying sting operations gives room to better understand U.S. society. This tactic advances a particular ideological understanding of the world. This ideology sees the 
world as dangerous and the U.S. government as protector. It is a configuration that led to wars around the world, wars that have claimed millions of lives. Security authors suggest this is not an inevitable condition. Governments make choices in the ways they conduct policy. A government can choose sting operations against its most vulnerable citizens. Or a government can choose to care for those citizens and attempt to understand why terrorism occurs. In the end, these choices come to define the nature of peace. Peace can either be an endless campaign of preemptive intervention that orients around flashpoints of violence; or, peace can be promotion of social welfare, sustainable community relations, and understanding. F.B.I. stings are one area discursive security is negotiated and the meaning of peace is made clear. 


\section{References}

Aaronson, T. (2013). The Terror Factory: Inside the FBI's Manufactured War on Terrorism. Brooklyn: IG Publishing.

Agamben, G. (1995). Homo Sacer: Sovereign Power and Bare Life. Stanford, CA: Stanford University Press.

Agamben, G. (2002). Security and terror. Theory and Event, 5(4), 1-3.

Althusser, L. (1971). Ideology and ideological state apparatuses (notes towards an investigation). Lenin and Philosophy and Other Essays, 1971-127.

Arnold, T. C. (2006). Executive power, the War on Terrorism, and the idea of rights. Politics \& Policy, 34(4), 670-688.

Attride-Stirling, J. (2001). Thematic networks: An analytic tool for qualitative research. Qualitative Research, 1(3), 385-405.

Balzacq, T. (2010). A theory of security: Origins, core assumptions, and variants. In T. Balzacq (Ed.), Securitization Theory: How Security Problems Emerge and Dissolve (pp. 1-30). London, Routledge.

Boykoff, M.T. \& Boykoff, J.M. (2004). Balance as bias: Global warming and the US prestige press. Global Environmental Change, 14(2), 125-136.

Brown, D. (2004). The War on Terrorism would not be possible without NATO: a critique. Contemporary Security Policy, 25(3), 409-429.

Burns, R. N. \& Price, J.(2013). The Arab revolutions and American policy. Aspen: Aspen Strategy Group. 
Busch, N.E., \& Pilat, J.F.(2013). Disarming Libya? A reassessment after the Arab Spring. International Affairs, 89(2), 451-475.

Butler, J. (2006). Precarious Life: The Powers of Mourning and Violence, Verso.

Cameron, D. (2001). Working with Spoken Discourse. Los Angeles: Sage Publications.

Cameron, D. \& Panovic, I. (2014). Working with Written Discourse. Los Angeles: Sage Publications.

Campbell, D. (1992). Writing Security: United States Foreign Policy and the Politics of Identity. Minneapolis: University of Minnesota Press.

Carasik, L. (2015, April 10). Americans have yet to grasp the horrific magnitude of the 'war on terror'”. Al Jazeera. Retrieved from http://america.aljazeera.com/opinions/2015/4/americans-have-yet-to-grasp-thehorrific-magnitude-of-the-war-on terror.html?utm_content $=$ opinion\&utm_campaign=ajam\&utm_source=facebook \&utm_medium=SocialFlow.

Chaffee, S. H. (1991). Explication. Newbury Park, Calif.: Sage Publications Inc.

Chomsky, N. (2003). Radical Priorities. Edinburgh: AK Press.

Conley, D. (2010). The joys of victimage in George W. Bush's war of totality. Cultural Studies/Critical Methodologies, 10(4), 347-357.

Corbin, J. \& Strauss, A. (1990). Grounded theory research: Procedures, cannons, and evaluative criteria. Qualitative Sociology, 13(1), 3-21.

Crampton, J. (2010). Foucault on politics, security and war. Environment \& Planning D: Society \& Space, 28(6). 
Creswell, J.W. (2006). Qualitative Inquiry and Research Design. Thousand Oaks, CA: Sage Publications.

Cuomo, C. J. (1996). War is not just an event: Reflections on the significance of everyday violence. Hypatia, 11(4), 30-45.

Der Derian, J. (1991). The terrorist discourse: Signs, states, and systems of global political violence. In M.T. Klare \& D.C. Thomas (Eds.), World Security (pp. 237 265). New York: St. Martin's Press.

Der Derian, J. (2002). 9/11: Before, after, and in between. Understanding September, 11, 177-190.

Der Derian, J. (2003). Decoding the national security strategy of the United States of America. Boundary 2, 30(3), 19-27.

Der Derian, J. (2008). Imagining terror: Logos, pathos and ethos. Third World Quarterly, 26(1), 23-37.

Der Derian, J. (2009). Virtuous War. New York: Routledge.

Dillon, M. (2008). Underwriting Security. Security Dialogue, 39(2-3), 2-3.

Eagleton, T. (1979). Ideology, fiction, narrative. Social Text, 2, 62-80.

Ehrlich, S. \& Romaniuk, T. (2014). Discourse analysis. In R.J. Podesva and D. Sharma (Eds.), Research Methods in Linguistics (pp. 460-493), Cambridge: Cambridge University Press.

Eid, M., \& Karim, K. (2011). Ten years after 9/11: What have we learned? Global Media Journal- Canadian Edition, 4 (2), 1-12.

Evans, B. (2010). Foucault's legacy: Security, war and violence in the 21 st century. 
Security Dialogue, 41(4), 413-433.

Falk, R.A. (1991). Theory, realism, and world security. In M.T. Klare \& D.C. Thomas (Eds.), World Security (pp. 6-24). New York: St. Martin's Press.

Fairclough, N. (2011). CDA in times of crisis. Retrieved from http://www.academia.edu/3776000/Critical_Discourse_Analysis_in_a_Time_of_ Crisis_2011_

Fairclough, N. (2013a). Critical Discourse Analysis: The Critical Study of Language. London \& NY: Routledge.

Fairclough, N. (2013b). Language and Power. NY: Routledge.

Fairclough, N. \& Wodak, R. (1997). Critical discourse analysis. In T. van Dijk (Ed.) Discourse Studies: A Multidisciplinary Introduction (pp. 258-284). London: Sage Publications.

Foucault, M. (1972). The Archaeology of Knowledge. NY: Random House/Pantheon Books.

Foucault, M. (2004). The Birth of Biopolitics: Lectures at the College de France. NY: Palgrave MacMillan.

Fried, A. (2005). Terrorism as a context of coverage before the Iraq war. Harvard International Journal of Press/Politics, 10(3), 125-132.

Galtung, J. (1969). Violence, peace, and peace research. Journal of Peace Research, 6(3), $167-191$.

Gee, J. P. (2007). Social linguistics and literacies: Ideology in discourses. Routledge. Gorman, S. (2004). Second-class security. National journal., 36(18), 1336. 
Gramsci, A. (1996). Prison notebooks: (Vol. 2). New York: Columbia University Press.

Grewal, B. S. (2003). Johan Galtung: Positive and negative peace. School of Social Science, Auckland University of Technology, 30.

Hawks, B.B. \& Baruh, L. (2011). If It Was Not for Terrorism: Crisis, Compromise, and Elite Discourse in the Age of 'War on Terror'. Cambridge: Cambridge Scholars Publishing.

Hay, B. (2005). Sting operations, undercover agents, and entrapment. Missouri Law Review, 70(2), 387- 431.

Hodges, A. (2011). The “War on Terror" Narrative: Discourse and Intertextuality in the Construction and Contestation of Sociopolitical Reality. Oxford: Oxford University Press.

Iguarta, J. J. \& Cheng, L. (2009). Moderating effect of group cue while processing news on immigration: Is the framing effect a heuristic process? Journal of Communication, 59, 726-749.

Johnson, T. \& Russell, J. (2005). A hard day's night? The United States and the global War on Terrorism. Comparative Strategy, 24(2), 127-151.

Kaplan, M. (2010). Review: US defense politics the origins of security policy, arsenal of democracy the Politics of national security. Canada's Journal of Global Policy Analysis, 65(3), 788-792.

Kapoor, P., Brehm, A., \& Testerman, A. (2014). Mohamud and the terror factory: A discourse analysis of local media coverage of the Christmas tree lighting episode. Paper presented at annual International Associated for Media and Communication 
Research Conference, Hyderabad, India.

Karampampas, S. (2009). The role of discourse in the social construction of security and terrorism: Deconstructing the "war on terror." Peace Studies, University of Bradford, 1, 3-69.

King, E.G. (1990). Thematic coverage of the 1988 presidential primaries: A comparison of USA Today and New York Times. Journalism Quarterly, 67(1), 83-87.

Leaman, G. (2004). Iraq, american empire, and the War on Terrorism. Metaphilosophy, $35(3), \quad 234-248$.

Maggio, J. (2007). The presidential rhetoric of terror: The (re)creation of reality immediately after 9/11. Politics \& Policy, 35(4), 810-835.

Morey, D. S., Thyne, C. L., Hayden, S. L., \& Senters, M. B. (2012). Leader, follower, or spectator? The role of President Obama in the arab spring uprisings. Social Science Quarterly, 93(5), 1185-1201.

Murakami, Y., Kawamura, N., \& Chiba, S. (2005). Toward A Peaceable Future: Redefining Peace, Security, and Kyosei from a Multidisciplinary Perspective. Pullman, WA: Thomas S. Foley Institute for Public Policy and Public Service.

Neal, A.W. (2008) Goodbye war on terror? Foucault and Butler on discourse of law, war and exceptionalism. In M. Dillon and A. Neal, Foucault on Politics, Security, and War (pp. 43-64). Palgrave MacMillan.

Neocleous, M. (2008). Critique of Security. Montreal: McGill-Queen's University Press. Noorani, Y. (2005). The Rhetoric of Security. CR: The New Centennial Review, 5(1), 1341. 
Richardson, J.E. (2007). Analyzing Newspapers: An Approach from Critical Discourse Analysis. Basingstoke: Palgrave Macmillan.

Owens, J. E. (2006). Presidential power and congressional acquiescence in the "war" on terrorism: A new constitutional equilibrium? Politics \& Policy, 34(2), 258-303.

Sanger, A. (2009). Myra Williamson: Terrorism, war and international law: The legality of the use of force against Afghanistan in 2001. Democracy and Security, 5(3), $316-319$.

Scollon, R. (2001). Action and text: Towards an integrated understanding of the place of text in social (inter)action, mediated discourse analysis and the problem of social action. In R. Wodak \& M. Meyer (Eds.) Methods of Critical Discourse Analysis (pp. 141-182). London: Sage Publications.

Sherman, J. (2009). A person otherwise innocent: Policing entrapment in preventative, undercover counterterrorism investigations, Journal of Constitutional Law, 11(5), $1475-1510$

Simpson, P. \& Mayr, A. (2010). Language and Power. NY: Routledge.

Straw, J. (2007). What's wrong with the War on Terrorism? Noted terrorism author and expert Brian Michael Jenkins discusses the fear factor and other problems with the U.S. War on Terrorism. Security Management., 51(9), 132.

Stevenson, D. (2008). Entrapment and terrorism. Boston College Law Review, 1(1), 125215.

Van Dijk, T. A. (1995). Ideological discourse analysis. New Courant, 4(1), 135-161. Van Dijk, T. A. (2006). Ideology and discourse analysis. Journal of Political Ideologies, 
11(2), 115-140.

Vultee, F. (2010). Securitization: A new approach to the framing of the 'war on terror'. Journalism Practice, 4 (1), 33-47.

Walsh, L., \& Barbara, J. (2006). Speed, international security, and 'new war' coverage in cyberspace. Journal of Computer-Mediated Communication, 12(1), 189-208.

Wodak, R., \& Meyer, M. (2009). Methods for Critical Discourse Analysis, $2^{\text {nd }}$ edition. London: Sage Publications.

Zizek, S. (2002). Welcome to the Desert of the Real! South Atlantic Quarterly, 101(2), $385-389$.

Zizek, S. (2011). Living in the End Times. [S.1.]: Verso Books. 


\section{Appendix: Newspaper Articles}

2 arrested in terror-money sting operation. (2004, August 6). The USA Today, p. 6A.

2 Albany men are arrested in plot to import a missile and kill a diplomat. (2004, August 6). The New York Times, p. B1.

2 men, in New York and Florida, are charged in Qaeda conspiracy. (2005, May 30). The New York Times, p. A1.

4 Accused of bombing plot at Bronx synagogues. (2009, May 21). The New York Times, p. A1.

A favor for a felon; why Ollie North 'cabaled quietly' for a jailed general. (1994, May 29). The Washington Post, p. C1.

A look at: The future of internationalism; beyond national interests. (1999, April 18). The Washington Post, p. B03.

A marked man in America. (2011, March 20). The New York Times, p. MM34.

Alexandria man admits plot to bomb the capitol. (2012, June 24). The Washington Post, p. A01.

Around the nation. (2009, January 27). The Washington Post, p. A02.

Behind scenes, informer's path led U.S. to 20 terror cases. (2004, November 18). The New York Times, p. B1.

Blood ties. (2015, April 12). The New York Times, p. BR1.

Bomb plot foiled at holiday event in Portland, ORE. (2010, November 28). The New York Times, p. A1.

Civil liberties today. (2011, September 11). The New York Times, p. F14.

Defendant tells terror trial he was training for Bosnia. (1995, August 22). The New York Times, p. B2.

Defendant's lawyer claims anti-Muslim bias in charges. (2005, June 1). The New York Times, p. B3.

Defense challenges F.B.I. over bomb plot. (1995, July 6). The New York Times, p. B5. 
F.B.I. agents' role is transformed by terror fight. (2009, August 19). The New York Times, p. A1.

F.B.I. role in terror probe questioned; lawyers points to fine line between sting and entrapment. (2006, September 2). The Washington Post, p. A01.

F.B.I.'s top spy catcher focuses on 'huge' threat of economic espionage. (2010, May 10). The USA Today, p. 4B.

Federal court jury finds sheik guilty of conspiracy and financing terrorism. (2005, March 11). The New York Times, p. B1.

General Vang Pao's last war. (2008, May 11). The New York Times, p. MM48.

Germany arrests 2 Yemeni men at hotel; sources say terrorism suspects were lured to Frankfurt in apparent sting. (2003, January 11). The Washington Post, p. A18.

Holder urges action on radicals trained in Syria. (2014, July 9). The Washington Post, p. A07.

Holder urges nations to adopt U.S. tactics on terror. (2014, July 9). The New York Times, p. A9.

Human rights report criticizes terror prosecutions. (2014, July 22). The Washington Post, p. A07.

Human sources: Risk and reward; covert aid programs put Casey's teams in the palace to recruit. (1987, September 30). The Washington Post, p. A1.

Identity crisis; meet Michael Berry: Political activist, cancer survivor, creditor's dream. Meet Michael Berry: Scam artist, killer, the real Michael Berry's worst nightmare. (2003, August 10). The Washington Post, p. W14.

If Higgins were Russian, would he be free now? (1988, February 28). The Washington Post, p. C1.

In paper war, flood of liens is the weapon. (2013, August 24). The New York Times, p. A1.

In wartime, deceit can be the better part of valor. (2004, October 17). The Washington Post, p. B05.

Informants vital in F.B.I.'s war on terror; one helped bring in man accused in D.C. bomb 
plot. (2012, February 22). The USA Today, p. 2A.

Iraq aside, French view the U.S. with a mixture of attraction and repulsion. (2003, November 13). The New York Times, p. A14.

Judge imposes 16-year term for Manhattan man in pipe bomb case. (2014, March 26). The New York Times, p. A20.

Jury hears 2 views of man accused in missile scheme. (2005, January 5). The New York Times, p. B5.

Lebanese hijacking suspect is denied bail at hearing in U.S. (1987, September 23). The New York Times, p. A10.

Man, 29, admits plot on capitol. (2012, June 23). The Washington Post, p. B01.

Man charged with attempt to bomb U.S. capitol. (2012, February 18). The Washington Post, p. A01.

Monitoring America. (2010, December 20). The Washington Post, p. A01.

Nation in brief. (2004, October 9). The Washington Post, p. A32.

Nation in brief. (2005, May 30). The Washington Post, p. A09.

N.Y. bomb plot suspects acted alone, police say. (2009, May 22). The New York Times.

Open U.S. checkbook to stem terror may soon snap shut. (2012, October 25). The New York Times, p. A1.

Pa. man accused of plot to hit pipelines; F.B.I. says he sought to aid Al Qaeda. (2006, February 13). The Washington Post, p. A10.

Protect airliners from missile attacks. (2003, August 18). The USA Today, p. 11A.

Scheme by 2 to train terrorists is outlined in U.S. court papers. (2005, May 31). The New York Times, p. B1.

Spy agency data after Sept. 11 led F.B.I. to dead ends. (2006, January 17). The New York Times, p. A1.

Spying programs may be tested by terror case. (2007, August 8). The New York Times, p. A1. 
Still not tired. (2009, October 4). The New York Times, p. WK9.

Sting hints at U.S. tactics on terror; details emerge in Frankfurt investigation of cleric tied to Bin Laden. (2003, February 23). The Washington Post, p. A14.

Tangled U.S. objectives bring down spy firm; private agents snared Afghan drug kingpin. (2008, December 27). The Washington Post, p. A01.

Terror suspects had no explosives and few contacts; Sears tower plan never finished, authorities say. (2006, June 23). The Washington Post, p. A03.

Terrorism guilty pleas by 2 in Sri Lankan separatist group. (2009, January 28). The New York Times, p. A22.

Terrorist recruiters leverage the web; from YouTube to Pakistan; N.Va men allegedly drafted to fight U.S. troops abroad. (2009, December 12). The Washington Post, p. A01.

The F.B.I. spins its terrorism web; a little-known office snares thousands of potential leads on the internet. (2001, November 15). The Washington Post, p. C01.

The rise of the F.B.I.; congress is handing the bureau new powers, creating a national police system that draws on military and intelligence resources. (1997, July 20). The Washington Post, p. W10.

The terror conspiracy: The verdict; mountains of evidence, but questions remain. (1995, October 2). The New York Times, p. B5.

The White House crisis: A shadowy side of the arms trade; Iranian agents built wide network to smuggle in weapons from U.S. (1986, December 5). The New York Times, p. A14.

Threats and responses: Financing terror; millions raised for Qaeda in Brooklyn, U.S. says. (2003, March 5). The New York Times, p. A1.

Trying to thwart possible terrorists quickly, F.B.I. agents are often playing them. (2005, May 30). The New York Times, p. A10.

Two views of terror suspects: Die-hards or dupes. (2006, July 1). The New York Times, p. A1.

U.S. accuses 13 of plotting to buy arms for Sri Lankan rebels. (2006, August 22). The 
New York Times, p. B1.

U.S. arrests suspected Tamil Tiger supporters; probe focused on weapons and cash. (2006, August 22). The Washington Post, p. A09.

U.S. foils swaps of drugs for weapons; Ashcroft announces arrests in two cases. (2002, November 7). The Washington Post, p. A03.

U.S. holds Briton on missile charge. (2003, August 12). The New York Times, p. A1.

U.S. is trying to counter ISIS's effort to lure alienated young Muslims. (2014, October 5). The New York Times, p. A24.

U.S. says Yemeni cleric aided Al Qaeda; man boasted of giving Bin Laden \$20 million before Sept. 11, officials state. (2003, March 5). The Washington Post, p. A00.

Use of stings is subject of debate. (2012, November 26). The Washington Post, p. B01.

Washington guardsman charged with trying to spy for Al Qaeda. (2004, February 19). The New York Times, p. A1.

We can trap more crooks with a new full of honey. (2004, January 11). The Washington Post, p. B01.

When do we call it terrorism? (2013, April 21). The Washington Post, p. B05.

You can't talk to an F.B.I. agent that way, or can you? (2005, June 5). The New York Times, p. B1. 